The author team submitted the following manuscript revision to Earth Surface Processes and Landforms (ESPL) on Sept 29, 2020. This version comprises the first revision to this manuscript originally submitted for publication in ESPL in March of 2020.

\title{
Rapid Tidal Marsh Development in Anthropogenic Backwaters
}

\section{Key Points:}

1. Shoreline development along a major urban estuary served as the primary trigger for freshwater tidal wetland development.

2. Marshes have developed and expanded rapidly in shallow settings after structures reduced hydrodynamic energy and increased sediment trapping efficiency.

3. Stratigraphic evidence and historical maps and aerial photos show that more than half of the tidal marsh area in the Hudson River developed in response to shoreline modification.

\section{Authors}

Brian Yellen ${ }^{1}$, Jonathan Woodruff ${ }^{1}$, Caroline Ladlow $^{1}$, David K. Ralston ${ }^{2}$, Sarah Fernald ${ }^{3}$, Waverly Lau $^{1}$

\section{Affiliations}

${ }^{1}$ University of Massachusetts, Amherst, MA, USA

${ }^{2}$ Woods Hole Oceanographic Institution, Woods Hole, MA, USA

${ }^{3}$ New York State Department of Environmental Conservation, Hudson River National Estuarine Research Reserve, Staatsburg, NY, USA

For Earth Surface Processes and Landforms, first revision, Sept 2020.

\section{Abstract}

Tidal marsh restoration and creation is growing in popularity due to the many and diverse set of services these important ecosystems provide. However, it is unclear what conditions within constructed settings will lead to the successful establishment of tidal marsh. Here we provide documentation for widespread and rapid development of tidal freshwater wetlands for a major urban estuary as an unintended result of early industrial development. Anthropogenic backwater areas established behind railroad berms, jetties, and dredge spoil islands resulted in the rapid accumulation of clastic material and the subsequent initiation of emergent marshes. In one case, historical aerial photos document this transition occurring in less than 18 years, offering a timeframe for marsh development. Accretion rates for anthropogenic tidal marshes and mudflats average $0.8-1.1 \mathrm{~cm} \mathrm{yr}^{-1}$ and $0.6-0.7 \mathrm{~cm} \mathrm{yr}^{-1}$ respectively, equivalent to 2-3 times the rate of relative sea level rise as well as the observed accretion rate at a $6000+$ year old reference marsh in the study area. Paired historical and geospatial analysis revealed that more than half of all the tidal wetlands on the Hudson River were likely triggered by anthropogenic development since the onset of the industrial era, including two thirds of the emergent cattail marsh. These inadvertently constructed tidal wetlands currently trap roughly $6 \%$ of the Hudson River's sediment load. Results indicate that when sediment is readily available freshwater tidal wetlands can develop relatively rapidly in sheltered settings. The study sites serve as useful examples to help guide future tidal marsh creation and restoration efforts. 


\section{Introduction}

Tidal marshes provide many well-documented ecosystem services including habitat or forage for important fisheries (Boesch and Turner, 1984; Kneib, 1997; Minello et al., 2012), filtering and detoxifying terrestrial runoff (Brin et al., 2010; Nelson and Zavaleta, 2012), and buffering coasts from wave energy and storms (Cochard et al., 2008; Gedan et al., 2011; Knutson et al., 1982). At the same time, tidal marshes face several threats, most notably from accelerating sea level rise (Crosby et al., 2016; Törnqvist et al., 2020), reductions in sediment supply (FitzGerald and Hughes, 2019), impediments to landward migration (Schuerch et al., 2018; Spencer et al., 2016; Thorne et al., 2018), and land reclamation (Lewis et al., 2019; Gu et al., 2018). Marsh peats found well below present day sea level in off-shore settings provide examples of marshes that did not keep pace with prehistoric sea level rise (Emery et al., 1965; Wolters et al., 2010). Marshes that have survived have done so by migrating inland to higher elevation substrate or by accreting organic material and mineral sediment in order to maintain surface elevation close to mean high tide. Disruptions in sediment supply to the coast due to trapping behind dams (Blum and Roberts, 2009) compound threats posed by accelerated sea level rise. Reduced sediment supplies due to improved agricultural practices (Kirwan et al., 2011) and hardening of shorelines (Peteet et al., 2018) have also been linked to tidal marsh deterioration.

Humans have long modified the coastline for agricultural purposes, with the dike-polder landscape of Northern Europe presenting perhaps the most prominent example (Meier, 2004); however examples exist along many low-lying coastlines, including those of Bangladesh (Ali, 2002), China (Yan et al., 2019), Vietnam (Biggs, 2012), and elsewhere. The well-documented means of polder construction in Northern Europe consisted of brushwood groins built across tidal flats in order to reduce wave activity and currents, thereby enhancing sedimentation and initiating marsh growth (Meier, 2004). Due to the abundant sediment supply in areas of the North Sea, this brushwood groin technique was particularly effective, initially increasing tidal flat elevations by $5-15 \mathrm{~mm} / \mathrm{yr}$ (Nolte et al., 2013), and by as much as 30 $\mathrm{cm}$ in less than a given year (Hofstede, 2003). Most of these new marsh systems were then historically diked off and used for agriculture. Embankments of some polders have been intentionally breached to restore tidal marsh communities and associated ecosystem services (Wolters et al., 2005).

Recently there has been renewed interest in the creation of tidal wetlands to off-set widespread historical marsh losses (Boorman et al., 2002; Craft et al., 2002). In order for emergent vegetation to become established within the intertidal zone, the substrate of any constructed tidal marsh must be at the correct tidal elevation (Broome et al., 2019). In naturally developed Holocene tidal marshes, this elevation has been achieved by initial accumulation of predominantly clastic material in sheltered low energy environments (Allen, 2000; Long et al., 2006). Void spaces make up much of the volume of the accreted material on marsh platforms (Turner et al., 2000), and decrease with depth due to the mass of overlying material and organic matter degredation (e.g. Allen, 2000; Brain et al., 2017). Marsh sustainability therefore requires that organic and inorganic sediment accretion keep pace with the compounding impacts of sea level rise and sediment autocompaction (Cahoon et al., 1995). Emergent low marsh can quickly build elevation as marsh grasses increase friction, reduce current velocities, and hasten the trapping of allochthonous suspended sediment (Bouma et al., 2005) and suspended particulate organic material (Mariotti et al., 2020). In addition to trapped sediment, marsh grass growth produces autochthonous vegetative material mainly via its roots, further contributing to marsh platform elevation. As the elevation of a marsh platform nears the level of high tide, the duration and depth of tidal inundation decreases. In prograding marshes, the horizontal distance between the high marsh and the marsh edge increases. Over time this reduction in tidal inundation and increased distance to the 
marsh edge reduces the transport and trapping of suspended sediment, causing in situ organic production to become the main contributor to continued marsh accretion (French and Spencer, 1993).

Within the densely developed coastlines of the Northeast US, tidal restoration via the removal of culverts or barriers to tidal circulation is the most common restoration method (Neckles et al., 2002; Warren et al., 2002), with several studies documenting success in replicating natural marsh habitat metrics. Additionally, new marshes have been intentionally created by placing dredge spoils in shallow, sheltered areas (Yozzo et al., 2004). In the US state of South Carolina, low marsh became established on dredge spoils with similar vegetation and faunal assemblages as nearby reference marshes in as little as four years (LaSalle et al., 1991). Other studies have documented similar findings, with restored marshes generally having high ecological index scores (Staszak and Armitage, 2012) and low colonization by invasive species after tidal restoration (Lechêne et al., 2018). These previous field studies have focused on restored extant marshes or intentionally creating new marshes to stabilize dredge spoil piles, and generally rely on observations made within $<10$ years following restorative action.

In contrast to deliberate efforts to create or restore marshes, here we highlight marshes that have been inadvertently created in response to human activity, focused on tidal freshwater marshes developed since the onset of the industrial era within the Hudson River Estuary in New York State, USA. We use sediment cores and historical maps to show that these marshes formed in association with a diverse set of anthropogenic features, including railroad berms, dredge spoil piles, and jetties. Resulting decreases in hydrodynamic energy at these sites allowed for rapid accumulation of clastic sediments and establishment of emergent marsh vegetation. We compare lithologic characteristics of these young emergent marshes with those of a pre-industrial marsh to identify differences in their defining characteristics. Lastly, we detail the stages of marsh development to provide a conceptual model of successful marsh creation, which can be used as reference for tidal marsh restoration practitioners.

\section{Site Description}

\subsection{Hudson River Estuary}

The Hudson River drains a $~ 38,000 \mathrm{~km}^{2}$ watershed, with roughly $70 \%$ of the freshwater discharge and sediment supplied by the combined contributions of the Upper Hudson (above Troy, NY) and Mohawk Rivers. The remaining $30 \%$ of discharge for the lower Hudson is provided by tributaries draining directly into the tidal river below Troy (Panuzio, 1965; Abood, 1974). Mean annual freshwater river discharge at the Battery (river $\mathrm{km} 0$ ) is $550 \mathrm{~m}^{3} \mathrm{~s}^{-1}$, but is highly seasonal, with annual maxima often occurring during spring snowmelt events (Olsen et al., 1978). The region is micro-tidal, with an average tidal range of roughly $1.2 \mathrm{~m}$. Tides propagate roughly $240 \mathrm{~km}$ upriver from the Battery in New York City (river km 0, Fig. 1). The salinity front is generally located in river km 35-100 (between Hastings, NY and New Hamburg, NY), with the landward reach of the tidal river entirely fresh (Ralston et al., 2008). The entire tidal reach is referred to herein as the Hudson River Estuary following common practice (Nitsche et al., 2007). Past estimates of average annual sediment delivery to the estuary have varied, but generally fall within the range of 0.4 to $1.0 \mathrm{Mt} \mathrm{yr}^{-1}$ (Ralston et al., 2013). A more recent and thorough estimate places the total sediment delivery to the estuary at $1.2 \mathrm{Mt} \mathrm{yr}^{-1}$ (Ralston et al., 2020 PREPRINT).

\subsection{Geologic Setting}

Steep bedrock shorelines confine the Hudson River for much of its tidal reach, contrasting with the mouths of many large river systems along passive tectonic margins. Pleistocene glaciation overdeepened the valley, with bedrock eroded down as much as $200 \mathrm{~m}$ below the present day river surface (Worzel and Drake, 1959). The active river channel fills much of the narrow valley. As a result, 
there is limited space for tidal marsh development within the estuary (Tabak et al., 2016). In assessing the tidal marsh abundance and spatial distribution within a 2008 dataset (Cornell IRIS, 2011), we find that emergent tidal vegetation covers only $14 \mathrm{~km}^{2}$, two-thirds of which is located upstream of river km 150. For reference, the surface area of the tidal river itself is approximately $300 \mathrm{~km}^{2}$. The Northeast US generally has low sediment yields relative to global averages due to inactive tectonics and limited relief (Meade, 1982).

Humans have altered the region's landscape and consequent delivery of sediment to the Hudson River Estuary. Economic development in the late 1700s and throughout the 1800 s drove the construction of hundreds of mill dams on steep tributaries to the Hudson (Bruegel, 2002). However, many of these dams are small and built on natural knickpoints, and as such, only contain in total 2-3 years of typical annual sediment delivery to the estuary (Ralston et al., 2020). New York City developed the Croton River watershed for water supply in the early 1800s, likely reducing this direct sediment supply to the saline estuary. The city expanded to the Catskill watershed of the Rondout, Esopus, and Schoharie rivers in the early 1900s. The Ashokan Reservoir (built 1915) on the Esopus River traps roughly $97 \%$ of the sediment from its upstream catchment (Ralston et al., 2020). Deforestation was extensive, with $80-90 \%$ removal of old growth forest peaking in roughly 1850 (Kudish, 2000). It remains unclear to what extent deforestation resulted in greater sediment loads, with lake records in neighboring Vermont showing limited impacts (Cook et al., 2015), but sedimentary records in the western Hudson River watershed show a distinct increase in erosion coincident with deforestation (Hilfinger IV et al., 2001). Climate change has generally made this region wetter, resulting in increased flood frequency (Armstrong et al., 2012), which is contributing to increasing erosion and resultant sediment loads (Cook et al., 2015; Yellen and Steinschneider, 2019).

Bedrock composition varies along the tidal river, but can generally be lumped into four main physiographic provinces. To the east of the river, the Taconic uplands are characterized by low-grade metamorphic calcareous and micaceous rock units that readily form fine-grained soils. Localized outcrops of high grade metamorphic rocks make up the higher ridges of the Taconics (Faber, 2002). West of the river, much of the watershed falls within the Catskill physiographic province, with bedrock made up of clastic sedimentary rocks, including shales that tend to form fine grained soils (McHale and Siemion, 2014). As a result of fine soil texture and steep slopes, Catskill streams are more prone to high turbidity than surrounding regions (Ahn et al., 2017). Much of the valley floor falls within the HudsonMohawk Lowlands, underlain by Cambrian and Ordovician age sedimentary rocks that have been preferentially eroded. Glaciofluvial and glaciolacustrine sediments associated with Glacial Lake Albany, which existed during the retreat of the Wisconsin Ice Sheet, mantle much of the valley floor (Rayburn et al., 2007). In its lower reaches, the tidal river flows through a canyon within erosion-resistant crystalline rocks of the Hudson Highlands, characterized by thin soils (Olsson, 1981).

\subsection{Hudson River Anthropogenic Changes}

Beginning in the mid-1800s, large-scale projects made several changes to the channel and shorelines of the Hudson River tidal reach. The Hudson River Railroad, completed between 1849 and 1851, runs directly along the east shore of the river, often crossing shallow embayments (Aggarwala, 1993). A competing rail line, The West Shore Railroad, was constructed in segments during the $1860 \mathrm{~s}$ and $1870 \mathrm{~s}$ ("Opening the West Shore," 1883), and similarly crosses many shoals between headlands on the west side of the Hudson. 
Historically the upper estuary channel (river km 190 to 240) was braided and shallow, impeding navigation. The federal government took control of Hudson River navigation projects in 1831, constructing a number of longitudinal dikes to constrict flow and increase scour in the main channel (Collins and Miller, 2012). Additionally, the channel has been actively dredged and deepened since the 1800s (Miller et al., 2006). This same dredging and channel deepening increased the tidal range at the head of the estuary by roughly $0.8 \mathrm{~m}$, largely by reducing drag and increasing drainage efficiency, which has served to lower low tides and decrease the magnitude of fluvial flooding (Ralston et al., 2019). Dredging efforts deepened the navigational channel in 1867, 1925, and 1932, resulting in a doubling of channel depths from roughly $10 \mathrm{~m}$ to $20 \mathrm{~m}$ for much of the Hudson's tidal reach. Within river km 185241 , dredge spoils filled in approximately $13 \mathrm{~km}^{2}$ of former shallow and intertidal habitat during the 20th century (Miller et al., 2006). In 1819 the average channel depth in the upper tidal river was just over $1 \mathrm{~m}$, but since the 1930s, a $9.7 \mathrm{~m}$ deep channel has been maintained (Collins and Miller, 2012). Piers cutting across the channel to lighthouses and other features were also constructed throughout the 19th and 20th centuries, including the Saugerties lighthouses at the mouth of Esopus Creek, one of our study sites. The majority of these shoreline modifications occurred during an era of reforestation and rapid dam building in the watershed, both of which would have potentially reduced sediment supply to the estuary.

\subsection{Study sites}

We focus here on five Hudson tidal freshwater wetland complexes associated with significant anthropogenic shoreline alterations (Fig 1). We used sediment cores and historical aerial imagery to reconstruct wetland development, focusing on sediment characteristics, accumulation rates and constraints on the timing of emergent marsh. Three of our sites are in coves bounded by railroad berms that were completed in 1851: Tivoli North Bay, Tivoli South Bay, and Vanderburgh Cove. Each of these sites represents a different stage in wetland development, progressing from open water and tidal flat towards emergent marsh. Tivoli North Bay is completely colonized by marsh, with cattail (Typha angustifolia) making up the dominant cover. Vanderburgh Cove is $53 \%$ open water with the remaining portion made up of emergent cattail marsh (14\%) and lower intertidal vegetation (31\%), mostly consisting of spatterdock (Nuphar advena). Tivoli South Bay is $95 \%$ open water, with the remaining area spatterdock (4\%) and cattail (1\%). Open water areas of all three railroad-bounded coves are dominated seasonally in the summer by invasive water chestnut (Trapa natans), which was introduced in 1884 (Smith, 1955). Two culverts under the railroad causeway berms allow for tidal exchange from the Hudson to Tivoli North Bay and Vanderburgh Cove, and three culverts connect the Hudson to Tivoli South Bay (black arrows in Fig. 1D and 1F). Small local tributaries also discharge into the three railroad impounded coves, all with similar watershed areas of $\sim 60 \mathrm{~km}^{2}$ (Table 1 ).

Two additional anthropogenic sites are not significantly impacted by railroad berms and instead remain more open. Stockport Marsh is located in the lee of a large promontory built from dredge spoils, with an associated prograding sand spit protecting the marsh from higher energy conditions. Esopus Marsh, at the delta of the Esopus River, is protected by three radial jetties that were constructed to maintain a tributary navigational channel and to provide access to a lighthouse since 1888 (Ladlow, 2019). Key attributes of all five anthropogenically modified coves and marshes are detailed in Table 1. Finally, a sixth site, lona Island Marsh, was evaluated as a control, as it has been a marsh since at least 6.8 kya (Chou and Peteet, 2010) due to naturally sheltered conditions behind a bedrock island (Fig. 1E). The 
West Shore Railroad was constructed across lona Island in 1870, but post-dates marsh development as documented in Chou and Peteet (2010), and by historical maps.

\section{Methods}

\subsection{Sample Collection}

Transects of sediment cores were collected from each tidal cove by methods determined by site conditions. At the open-water Tivoli South Bay site, piston push coring conducted at high tide was used to recover $2.2 \mathrm{~m}$ overlapping drives. At all other sites, a $6.3 \mathrm{~cm}$ diameter gouge corer was used to collect $1 \mathrm{~m}$ overlapping drives. Both of these coring methods are well suited to recovering uncompacted sediments, such that core depth reflects true depth below grade. When highly porous and fibrous marsh surface sediment caused poor gouge core recovery, a $5 \mathrm{~cm}$ diameter Russian peat corer was used to collect $0.5 \mathrm{~m}$ long surface drives. At nearly all core sites (see Fig. 1 for locations), successive drives were collected until a resistant stratum below marsh or cove muds was reached. This resistant layer was either sandy mud or massive grey clay visibly devoid of organic material.

\subsection{Sample Analysis}

Cores were transported to the University of Massachusetts Amherst where they were split, described, and stored at $4^{\circ} \mathrm{C}$. Split cores were scanned using an ITRAX $\mathrm{x}$-ray fluorescence (XRF) core scanner with a molybdenum tube running at $30 \mathrm{kV}$ and $55 \mathrm{~mA}$ with ten-second exposure times (Croudace et al., 2006). Similar XRF settings have been employed for past studies on the Hudson and where the relative abundance of XRF-obtained $\mathrm{Zn}$ has been shown to be particularly effective in identifying the industrial onset of heavy metals (Brandon et al., 2014).

Every $10 \mathrm{~cm}$ and above and below visible lithologic transitions we removed a $1 \mathrm{~cm}$ thickness subsample for determination of bulk density, percent organic content, and grainsize. Subsamples were weighed wet and dry and then combusted, with change in sample mass calculated after each step to derive water and organic mass from loss on ignition (LOI) following procedures in Dean, (1974), and dry bulk density based on the empirical LOI mixing model described by Morris et al. (2016). Dry bulk densities were also determined independently by assuming water content as a proxy for void space and inorganic and organic densities of $2.4 \mathrm{~g} \mathrm{~cm}^{-3}$ and $1.2 \mathrm{~g} \mathrm{~cm}^{-3}$, respectively (Neubauer, 2008), which provided similar results but tended to be biased high due to sediments likely not being fully saturated when obtaining wet weight. Burned samples were gently disaggregated with mortar and pestle then run through a Beckman Coulter LS 13320 laser diffraction particle size analyzer with a range of $0.4 \mu \mathrm{m}$ to $2000 \mu \mathrm{m}$, and sonicated for 15 seconds before measuring the sample for 60 seconds. An alternative digestion method using a double treatment of $30 \%$ hydrogen peroxide was also tested, but visual inspection of these processed samples under 100X magnification showed incomplete digestion of organic particles.

\subsection{Sediment age constraints}

We constrain sediment ages using down-core profiles of short-lived radionuclides via gamma spectroscopy and heavy metal chronologies from XRF core scanning. Visual observation of split cores revealed common stratigraphy discussed below that could be traced across individual transects. Following this visual inspection, one or two representative cores from each marsh transect were selected to obtain additional age constraints via down-core concentrations of ${ }^{137} \mathrm{Cs}$ and unsupported ${ }^{210} \mathrm{~Pb}$. For these short-lived radioisotopic analyses subsamples of $1 \mathrm{~cm}$ thickness and approximately $6 \mathrm{~g}$ 
dry mass were counted for at least 48 hr on a Canberra GL2020R Low Energy Germanium Detector. We primarily rely on the 1963 peak in ${ }^{137} \mathrm{Cs}$ as age and $1954 \mathrm{CE}$ onset following methods in Pennington et al. (1973). In cores that displayed decreases in ${ }^{210} \mathrm{~Pb}$ with depth, we further constrained sediment ages based on unsupported or excess ${ }^{210} \mathrm{~Pb}$ activities, defined as the difference between total ${ }^{210} \mathrm{~Pb}$ activities and the in situ supported ${ }^{210} \mathrm{~Pb}$ as measured by ${ }^{214} \mathrm{~Pb}$ (Chen et al., 2004). Unsupported ${ }^{210} \mathrm{~Pb}$ activities were converted to age using methods described by Appleby and Oldfield (1978) assuming a constant initial concentration $(\mathrm{ClC})$ of excess ${ }^{210} \mathrm{~Pb}$. All ${ }^{137} \mathrm{Cs},{ }^{210} \mathrm{~Pb}$ and ${ }^{214} \mathrm{~Pb}$ profiles, as well as derived age models, are presented in Ladlow (2019), and the ${ }^{137} \mathrm{Cs}$ and excess ${ }^{210} \mathrm{~Pb}$ derived chronologies were generally consistent.

The onset of increased heavy metals in cores is linked to the beginning of the industrial era and dates to 1850-1900 in the region (e.g. Olsen et al., 1978). Here we employ zinc as a general proxy for heavy metals as it has been shown to have the clearest industrial related onset and least noise among heavy metals evaluated by XRF core scanning (e.g. Brandon et al., 2014). A strong correspondence has also been observed between heavy metal profiles of $\mathrm{Zn}$ and $\mathrm{Pb}$ (e.g., Benoit et al., 1999), but with a much noisier $\mathrm{Pb}$ signal derived from the XRF scanning technique (Ladlow, 2019).

271 Historical maps and aerial photos were used to constrain the timing of anthropogenic impacts at each 272 study site, as well as to track the extent of tidal marsh through time. Topographic maps were accessed from the US Geological Survey's National Geologic Map Database Project. Historical navigation charts were accessed from NOAA's Office of Coast Survey's Historical Map \& Chart Collection. Aerial images were accessed via USGS's Earth Explorer application. These data sources were then used to map marshes that have formed within anthropogenic backwaters throughout the entire estuary using a 2007 geospatial dataset of the tidal wetland extent along Hudson River (Cornell IRIS, 2011).

\section{Results}

\subsection{Tivoli North Bay}

Our sampling of Tivoli North Bay (TVN) was composed of a west-to-east transect of five cores across the marsh surface (Fig. 1F). The transect began at TVN2 collected $110 \mathrm{~m}$ from a north-south oriented tidal channel that runs directly behind the railroad berm, followed west-to-east by TVN3, TVN1, TVN4 and TVN5 (Fig. 1), with the TVN5 core collected $10 \mathrm{~m}$ from the edge of another, larger tidal channel that runs along the landward side of the marsh. This landward tidal channel also serves as the fluvial outlet of Stony Creek, a small tributary that drains a local watershed of $55 \mathrm{~km}^{2}$.

We observed an abrupt up-core decrease in median grain size, from 20-40 $\mu \mathrm{m}$ to less than $10 \mu \mathrm{m}$ for a majority of cores in the transect (Fig. 2). For the four most eastern cores (TVN3, TVN1, TVN4 and TVN5), this onset to finer grained deposition occurred at a depth of between 160 and $170 \mathrm{~cm}$, and shallowed to a depth of roughly $135 \mathrm{~cm}$ in the most western TVN2 core. A gradual, and then more pronounced increase in organics is observed above the sharp coarse-to-fine grained transition, with the transition to greater organic fractions at a depth between roughly 70 and $90 \mathrm{~cm}$, increasing from approximately $10 \%$ LOI below to $35 \%$ LOI above. We observe this prominent surficial increase in organics for all cores except TVN5, where organics are observed to increase but remained below $20 \%$ LOI.

Chronological markers from zinc onset, ${ }^{137} \mathrm{Cs}$, and ${ }^{210} \mathrm{~Pb}$ inform a depth-to-age model for Tivoli Bay North (Fig. 3). The zinc profile for TVN3 in the upper $50 \mathrm{~cm}$ of the core was relatively noisy due to highly porous organic sediments and root matter. Below this surficial unit, an initial rise in zinc is observed at roughly $150 \mathrm{~cm}$. The ${ }^{137} \mathrm{Cs}$ depth profile for the same core reveals a $1954 \mathrm{CE}$ onset in detectible activity 
above $60 \mathrm{~cm}$, followed by a $1963 \mathrm{CE}$ peak at $35 \mathrm{~cm}$. We also isolated the $1954 \mathrm{CE}{ }^{137} \mathrm{Cs}$ onset in core TVN4 to a similar depth of $61 \mathrm{~cm}$, suggesting consistent deposition rates between cores (Fig. 2). We observed a general increase in total ${ }^{210} \mathrm{~Pb}$ activities towards the surface in TVN3, with the exception of two samples counted between 20 and $40 \mathrm{~cm}$. Supported ${ }^{210} \mathrm{~Pb}$, as defined by $\mathrm{Pb}-214$ activities, remained relatively uniform downcore in TVN3, indicating that trends in overall ${ }^{210} \mathrm{~Pb}$ activity likely also reflect variability in unsupported ${ }^{210} \mathrm{~Pb}$. ${ }^{210} \mathrm{~Pb}$-derived ages for TVN3 are not all chronologically consistent due to drops in activity between $20-40 \mathrm{~cm}$. However, the best fit to unsupported ${ }^{210} \mathrm{~Pb}$ derived ages results in a deposition rate of $0.9 \mathrm{~cm} / \mathrm{yr}$, which is consistent with independent accumulation rates based on the 1954 onset of ${ }^{137} \mathrm{Cs}$ and the industrial onset of zinc assuming a common age of $1850 \mathrm{CE}$ corresponding to railroad construction. A derived deposition rate of $0.9 \mathrm{~cm} / \mathrm{yr}$ for TVN3 dates the $165 \mathrm{~cm}$ lithologic transition to finer sediments in the core to the early-to-mid 1800s (Fig. 2). This rate is similar to, yet somewhat higher than, the range of $0.7-$ to $-0.8 \mathrm{~cm} / \mathrm{yr}$ obtained to the south of our transect in marshes fringing Cruger Island by Sritrairat et al., (2012) (white squares in Fig 1F).

\subsection{Tivoli South Bay}

Tivoli Bay South (TVS) is separated from Tivoli Bay North by a tombolo that extends from the eastern shore of the Hudson River to the bedrock outcrop that forms the center of Cruger Island (Fig. 1). In contrast to expansive tidal wetlands in Tivoli Bay North, Tivoli Bay South is predominantly tidal flats, with just a thin strip of emergent wetlands that flank its mainland shore. Similar to Tivoli Bay North, the west side of the bay is now defined by a railroad berm, through which three culverts serve as the primary tidal connections between the bay and the main Hudson River. An additional side tributary (Sawkill Creek), empties into to Tivoli Bay South to the east, draining a watershed of approximately 68 $\mathrm{km}^{2}$.

Three cores were collected along a west-to-east transect (Fig. 1F), spanning the widest part of the bay and terminating $210 \mathrm{~m}$ away from the mouth of Sawkill Creek. We observed a sharp drop in median grain size in all three of these cores at varying depths (Fig. 4), similar to observations from Tivoli Bay North cores (Fig. 2). The up-core decrease in $D_{50}$ was most apparent at the western TVS1 core, where at roughly $120 \mathrm{~cm}$ the median grain size decreased from $40 \mu \mathrm{m}$ to less than $4 \mu \mathrm{m}$. In TVS2 and TVS1 this drop in grain size occurred at shallower depths of $117 \mathrm{~cm}$ and $59 \mathrm{~cm}$, respectively. The drop in grain size in TVS2 was smaller in magnitude than TVS1, decreasing from about $20 \mu \mathrm{m}$ to $10 \mu \mathrm{m}$. Conversely, we observed a larger drop in grain size at TVS3, decreasing up-core from $>200 \mu \mathrm{m}$ to $20 \mu \mathrm{m}$. All cores from TVS showed a gradual rise in zinc just above their respective step-function drops in grain size, while organic content throughout these cores remained relatively low at roughly $5 \% \mathrm{LOI}$.

We observed a 1954 CE onset and 1963 peak in ${ }^{137} \mathrm{Cs}$ activity in TVS1 at roughly $40 \mathrm{~cm}$ and $35 \mathrm{~cm}$, respectively (Fig. 4). Farther down in TVS1, the onset for 1850 industrial-derived zinc began at $95 \mathrm{~cm}$ (Fig. 4). A complete depth profile of ${ }^{210} \mathrm{~Pb}$ was not obtained from TVS1; however, ${ }^{137} \mathrm{Cs}$ and zinc-derived ages are all consistent with an average deposition rate at TVS1 of 0.6 -to-0.7 $\mathrm{cm} \mathrm{yr}^{-1}$. We find this rate consistent to previous ${ }^{137} \mathrm{Cs}$-derived accumulation rates from Tivoli South Bay of $0.59,0.60,0.68,0.77$ and $0.93 \mathrm{~cm} \mathrm{yr}^{-1}$ presented by Benoit et al. (1999), but less than their average $1.16+/-0.3 \mathrm{~cm} / \mathrm{yr}$ when including rates derived from ${ }^{210} \mathrm{~Pb}$. Our ${ }^{137} \mathrm{Cs}$-derived deposition rate of $0.65 \mathrm{~cm} / \mathrm{yr}$ at TVS1 resulted in an approximate age for the core's grain-size transition at $120 \mathrm{~cm}$ of sometime between the early-and-mid 1800s, which was similar to the age obtained for the same transition at TVN3 and consistent with the 340 timing of railroad construction at both sites. 
We collected two transects of cores from Vanderburgh Cove (see Fig. 1 for core locations). A transect across the emergent marsh began at core site VBM3 near the tributary mouth of the Landsman Kill (watershed area of $61 \mathrm{~km}^{2}$ ), and progressed south to the center (VBM2), and distal edge (VBM1) of the marsh. A second Vanderburgh transect crossed the open-water tidal flat area of the cove beginning near the marsh edge (VBC4) and extending south to the center (VBC5) and southeastern side (VBC6) of the 348 cove.

Within core VBM1, we observed zinc onset and a concurrent grain size transition at a depth of $167 \mathrm{~cm}$ (Fig. 5), which is similar to the depth observed at Tivoli North. At $75 \mathrm{~cm}$ depth, the onset of leaf likely indicating the transition from intertidal mudflat to marsh, and supported by a gradual increase in LOI to $10 \%$ at the surface. VBM2 and VBM3 were less than $150 \mathrm{~cm}$ in length, with core recovery impeded by refusal in sandy material at that depth. This sandy material likely represented coarse deltaic deposits from Landsman Kill. Neither VBM2 nor VBM3 displayed a zinc onset or a transition in grain size (Fig. 5). VBM2 and VBM3 displayed generally greater organic contents than observed at VBM1, likely due to the rapid horizontal expansion of tidal wetlands at VBM1, as observed in historical aerial photos (Supp. Fig. 1). Historical aerial photos suggest that marsh at Vanderburgh did not emerge until after 1978. The marsh's position at the mouth of Landsman Kill and its recent emergence contrast with marsh development at Tivoli North, for which there is no evidence of marsh development beginning at a tributary mouth. In turn, at Vanderburgh we consider ${ }^{137} \mathrm{Cs}$-derived ages as a better representation of wetland accretion rates than ages derived from the earlier zinc onset. For the VBM1 marsh core we observe the 1954 CE onset and subsequent 1963 CE peak at respective depths of $94 \mathrm{~cm}$ and $90 \mathrm{~cm}$ (Fig. 5). These ${ }^{137} \mathrm{Cs}$ age constraints result in marsh accretion rates of $1.5-1.6 \mathrm{~cm} \mathrm{yr}^{-1}$, much greater than the rate of $0.9 \mathrm{~cm} \mathrm{yr}^{-1}$ obtained at Tivoli North Bay's marsh (Fig. 3).

Open water cores from Vanderburgh (VBC4-VBC6) all exhibited concurrent onsets in zinc and decreases in grain size similar to VBM1, at $112 \mathrm{~cm}, 133 \mathrm{~cm}$, and $104 \mathrm{~cm}$ respectfully. Above this transition, median grain size was between 8 and $14 \mu \mathrm{m}$ (fine silt) for all Vanderburgh cores with the exception of surface material in VBM2 and VBM3 (Fig. 5). Similar to Tivoli Bays, we interpret the drop in grain size in the VBC4-VBC6 cores as marking the timing of railroad construction in 1851 CE (Fig. 5), which results in subsequent accumulation rates of 0.6 to $0.8 \mathrm{~cm} \mathrm{yr}^{-1}$. If the lithologic transition at $167 \mathrm{~cm}$ in VBM1 also represents railroad construction, we obtain an accumulation rate of $0.7 \mathrm{~cm} \mathrm{yr}^{-1}$ for the interval below that 1954 onset for ${ }^{137} \mathrm{Cs}$, a rate similar to that observed in the open water portions of the cove.

\subsection{Stockport Marsh}

A series of nautical charts and aerial images from the twentieth century help to illustrate wetland development at the Stockport Marsh site. A nautical chart from 1915 shows that a delta extended west from the mouth of Stockport Creek approximately $200 \mathrm{~m}$, with a total areal extent of $5 \times 10^{4} \mathrm{~m}^{2}$ (US Coast and Geodetic Survey, 1915). South of Stockport Creek's mouth, a $<1 \mathrm{~m}$ deep shoal extended out approximately $600 \mathrm{~m}$ from the shore with no denotations for marsh. Nautical charts from 1929 indicate no significant change to this morphology (US Coast and Geodetic Survey, 1929). However, in 1930 a 6 $\mathrm{x} 10^{4} \mathrm{~m}^{2}$ island appeared at the western edge of the shoal directly to the west of Stockport Creek's mouth and grew to $1.9 \times 10^{5} \mathrm{~m}^{2}$ by 1932 (Fig. 6A). A 1953 topographic map indicates that much of this island was more than $3 \mathrm{~m}$ above sea level at that time, similar to its present elevation. The abrupt appearance of this feature and its elevation well above that of natural deltaic deposition suggest that dredge spoil emplacement created this island, which is consistent with the timing of major navigation improvements here during the late 1920s and early 1930s (Miller et al., 2006). By 1960, an aerial photo shows a spit extending southward from the dredge pile along the shallow shoal depicted in navigational 
charts (Fig. 6B). The embayment formed by this spit remained mostly open water in 1960. Conversely, a 1978 aerial photo shows that abundant emergent vegetation had developed during the 18 years that had elapsed since 1960 (Fig 6C).

We analyzed a north-to-south transect of cores from Stockport Marsh, with the most northern SPM7 nearest to the dredge spoil island, SPM4 in the center of the marsh, and SPM1 nearest to the southern edge of the marsh and $4 \mathrm{~m}$ away from a major tidal channel (Fig. 1). The sand-to-mud transition was most abrupt in SPM4 at approximately $95 \mathrm{~cm}$ (Fig. 7), with more gradual transitions in SPM7 and SPM1 centered at approximately $75 \mathrm{~cm}$ and $115 \mathrm{~cm}$, respectively. SPM7 and SPM4 exhibited similar increases in organic content above their respective sand-to-mud transitions, reaching peak values of $\sim 40 \% \mathrm{LOI}$ near the surface. The increase in organics was less evident closest to the marsh edge in SPM1, which is consistent with lower organic content in marsh edge observations from VBM1 (Fig. 5) and TVN5 (Fig. 2) and other studies of tidal marsh organic content (Palinkas and Engelhardt, 2016; Temmerman et al., 2003).

Depth profiles of ${ }^{137} \mathrm{Cs}$ from the center of the marsh (SPM4) identified a 1954 CE onset and 1963 CE peak at roughly $55 \mathrm{~cm}$ and $35 \mathrm{~cm}$ and respective average deposition rates of $0.9 \mathrm{~cm} / \mathrm{yr}$ and $0.7 \mathrm{~cm} / \mathrm{yr}$. ${ }^{1}$ At the marsh's southern edge (SPM1), the 1954 CE onset and $1963 \mathrm{CE}$ peak in ${ }^{137} \mathrm{Cs}$ was observed at depths of $106 \mathrm{~cm}$ and $61 \mathrm{~cm}$, with respective deposition rates of $1.7 \mathrm{~cm} / \mathrm{yr}$ and $1.1 \mathrm{~cm} / \mathrm{yr}$. This discrepancy in calculated deposition rates from ${ }^{137} \mathrm{Cs}$ onset (1954) to peak (1963) is consistent with rapid trapping of fine-grained sediment resulting from the concurrent development of the sand spit. Depth profiles of zinc from the SPM cores exhibited significant noise and data gaps; however, the onset for zinc in SPM7 appears to be deeper than the sand-to-mud transition (Fig. 7), which is also consistent with the sand-tomud transition in SPM7 dating to the 1930 emplacement of dredge spoils, well after industrial activity introduced heavy metals to this region.

\subsection{Esopus Marsh}

The Esopus marsh/delta complex lies on the western side of the Hudson River approximately three kilometers north of Tivoli Bays (Fig. 1). Esopus Creek drains a $1100 \mathrm{~km}^{2}$ watershed with sub-catchments known for higher-than-regional-average sediment yields (Ahn et al., 2018). Dredging began at the mouth of the Esopus in 1888, with jetties built on either side of the navigation channel to prevent shoaling ("Timeline - Saugerties Lighthouse," 2011). An 1863 nautical chart shows shoals in the areas to the north and south of these jetties that is now occupied by marsh. Historical maps are consistent with marsh development following jetty construction (Fig. 8).

We obtained a series of five cores from the Esopus Marsh complex including four to the south of the jetty-hardened channel (ESP1-ESP4) and one to the north (ESP5). The grain size profile from ESP3 reveals a sand-to-mud transition at $\sim 85 \mathrm{~cm}$ that is concurrent with the onset in zinc (Fig. 9). We observe a gradual rise in organic content above this sand-silt transition that begins below $3 \% \mathrm{LOI}$ and rises to values that range between 9 and $13 \%$ above a depth of $65 \mathrm{~cm}$. Activities of ${ }^{137} \mathrm{Cs}$ at ESP3 reveal a 1954 CE onset near the base of this greater organic content unit at $\sim 60 \mathrm{~cm}$, followed by a subsequent $1963 \mathrm{CE}$ peak at $50 \mathrm{~cm} .{ }^{137} \mathrm{Cs}$ age constraints from two cores both provide an approximate accumulation rate of $\sim 0.9 \mathrm{~cm} / \mathrm{yr}$ for recent marsh material.

Grain sizes for ESP1 and ESP2 were not obtained, however, LOI profiles for these cores revealed a similar $\sim 80 \mathrm{~cm}$ rise in organics as that observed in ESP3 (Fig. 10), as well as a concurrent rise in zinc. In the two 
cores that are closest to the Esopus channel (ESP4 and ESP5), we observed a deeper zinc onset and increased LOI at $120 \mathrm{~cm}$. We find that a higher rate of deposition at ESP5 based on zinc onset depth is consistent with ${ }^{137} \mathrm{Cs}$ activities obtained for the core, where the 1954 onset and 1963 peak were observed at $\sim 94 \mathrm{~cm}$ and $80 \mathrm{~cm}$, respectively (Fig. 10). The resulting ${ }^{137} \mathrm{Cs}$-derived accumulation rate for ESP5 is roughly $1.5 \mathrm{~cm} / \mathrm{yr}$. The organic content within surficial sediments at ESP5 was also the highest of all cores collected from the site, with LOI ranging between $20-30 \%$ above a depth of $\sim 40 \mathrm{~cm}$.

\subsection{Iona Island Marsh}

Iona Island is located on the western side of the Hudson and shelters a large wetland complex to its southwest, with $0.49 \mathrm{~km}^{2}$ of Typha and Phragmites marsh. Low salinity at lona Island Marsh of 1-2 ppt on average (Yozzo et al., 2005) suggests limited influence of salinity-driven sedimentation processes such as flocculation (Sholkovitz, 1976). A railroad crosses the island, with earthen berms extending north and south. A $25 \mathrm{~m}$ culvert allows for tidal exchange through the southern berm and a $250 \mathrm{~m}$ trestle supported by piers traverses the northern entrance.

Chou and Peteet (2010) recovered a core from the most sheltered portion of lona Island Marsh that showed peat down to $9 \mathrm{~m}$ with ${ }^{14} \mathrm{C}$ dates from marsh rhizomes placing marsh development there at least by 6.8 kya. We collected a transect of cores from the less sheltered portion of the marsh to evaluate changes in development and lithology following railroad construction (INA1-INA7; see Figure 1 for locations). We observed the 1954 onset of ${ }^{137} \mathrm{Cs}$ at $15 \mathrm{~cm}$ in INA5 and obtained a resulting deposition rate of $0.23 \mathrm{~cm} / \mathrm{yr}$. The $1850 \mathrm{CE}$ onsets for zinc in INA cores were observed between 35 and $45 \mathrm{~cm}$, consistent with relatively slow and uniform deposition rates throughout the marsh of between 0.2 and $0.3 \mathrm{~cm} / \mathrm{yr}$ (Figure 11). These vertical accumulation rates are 3-5 times less than those observed at our other study sites, which is consistent with pre-industrial development of lona Island Marsh and slower accretion rates controlled by sea level rise. Organic content of the peat here was typically greater than $50 \%$, with the exception of INA1, which was located adjacent to a major channel (Figure 11). The inorganic fraction of material in all cores was comprised predominantly of silt, with median grain sizes $\left(D_{50}\right)$ generally between $5 \mu \mathrm{m}$ and $20 \mu \mathrm{m}$. We observed no discernable changes in the organic fraction or grain size at the zinc onset, unlike other railroad causeway sites (TVN, TVS, and VBM), where zinc onset provided a regionally consistent proxy for the timing of railroad construction.

\subsection{Extent of Anthropogenic Marshes on the Hudson}

Given the stark contrasts in old versus anthropogenic marshes, and the sediment needs of rapidly developing anthropogenic marshes, we mapped tidal marshes that have formed during the industrial era to evaluate their aggregate impact on the sediment budget of the Hudson River Estuary. Beginning with a high resolution geospatial data set of Hudson tidal wetlands (Cornell IRIS, 2011), we identified those marshes that formed since $\sim 1900$. We used several data sets to identify past alterations to the river and resultant marsh development including navigational charts, air photos, and topographic maps. Using these historical resources, we estimate that $52 \%$ of marshes have developed in the shelter of dredge piles, dikes, jetties, and railroad berms since the mid-1800s. This is a conservative estimate, as only those marshes that were clearly documented as newly extant were classified as anthropogenic. Anthropogenic marshes have disproportionately fostered non-invasive Typha marsh, rather than Phragmites, with two thirds of all cattail marsh on the Hudson occurring within anthropogenic settings (Supp. Fig. 3). 
Most new marsh area since the mid-1800s has formed in the upper reaches of the tidal river between river $\mathrm{km} 193$ and 240, largely as a result of early $20^{\text {th }}$ century dredging and longitudinal dikes that transformed the formerly braided upper channel into a single, deeper navigational channel (Squires, 1992; Miller et al., 2006; Collins and Miller, 2012). A variety of tidal wetland types have colonized resultant braid channel cut-offs that provided shallow, low-energy environments.

\section{Discussion}

\subsection{Contrasting new and old marshes and tidal flats}

We group our field sites into three representative categories: (1) anthropogenic marshes that developed in response to human alterations (Tivoli North, Vanderburgh Marsh, Esopus, Stockport); (2) humanmodified coves that remain tidal mudflat with open water at high tide (Tivoli South and Vanderburgh Cove); and (3) natural marsh systems established prior to human alterations (Iona). For these categories we compiled values for observations of organic content, grain size, vertical accumulation rates derived from ${ }^{137} \mathrm{Cs}$ and zinc onset chronologies, and mineral accumulation rates in mass per unit area per time. The number of cores for each site ranged from three to five, and therefore, accumulation rates should be viewed with some caution in accordance with the sample size. For each site, we present average values of all measurements from 0-to-50 cm (Fig. 12), as this depth interval was observed to best capture elevated organics at marsh locations (e.g. Fig. 2, 5,7, and 10) and is consistent with analyses used elsewhere to compare tidal marsh organic content (Morris et al., 2016).

Iona Island Marsh, which was established > 6kya (Chou and Peteet, 2010), exhibits the lowest rates of vertical accretion ranging between 0.2 and $0.3 \mathrm{~cm} / \mathrm{yr}$ (Fig. 12A), consistent with this marsh remaining in step with $20^{\text {th }}$ century regional rates of sea level rise (Kemp et al., 2017). Iona accumulation rates are also similar to those published previously for regional marshes thought to be in steady state with sea level rise (Fig. 13), including Piermont Marsh (0.29 cm/yr in Pederson et al., 2005) and Jamaica Bay (0.32 $\mathrm{cm} / \mathrm{yr}$ in Peteet et al., 2018). Of all our study sites, the slowly accumulating lona Island Marsh had the greatest organic content, with an average LOI in the top $50 \mathrm{~cm}$ of $50 \%(+/-18 \%)$. Organic content for Iona was similar to that published previously from Piermont Marsh (37\%+/- 9\%, Pederson et al., 2005), and somewhat lower than that published from Jamaica Bay marsh $(61 \%+/-9 \%$, Peteet et al., 2018).

Accumulation rates for the anthropogenic marsh category were typically around $\sim 0.9 \mathrm{~cm} / \mathrm{yr}, 3-4$ times greater than those observed in lona Island Marsh (Fig. 12). Organic content in anthropogenic marshes was also substantially lower than the lona site, with average LOI values of 10-30\% (Fig. 12B). Compared to anthropogenic emergent marshes, human-modified coves (Vanderburgh and Tivoli South) exhibited somewhat slower accumulation rates, averaging between 0.6 and $0.7 \mathrm{~cm} / \mathrm{yr}$, but were still 2-3 times greater than rates of accumulation at Iona Island Marsh. Cove sediments also contain the least organic matter, with average LOI in the uppermost $50 \mathrm{~cm}$ typically below $10 \%$. At all sites, we observed predominantly silt-size clastic deposition, with median grain sizes between 5 and $20 \mu \mathrm{m}$, and no clear grain size delineations between marsh/cove categories (Fig. 12C).

The three categories of field site presented here (old marsh, new marsh, intertidal mudflat) display clear differences in their rates of vertical accumulation and mineral sediment storage. We observe approximately $0.3 \mathrm{~cm} \mathrm{yr}^{-1}$ greater rates of accumulation in anthropogenic marshes than in the anthropogenic coves. This $0.3 \mathrm{~cm} \mathrm{yr}^{-1}$ discrepancy is similar to the total accumulation rate at pre- 
industrial Iona Island Marsh. Iona Island Marsh has accreted largely through in-situ production of organic material, as indicated by its high organic content and relatively low rate of mineral accumulation (Fig. 12D). This is largely due to its maturity and high platform tidal elevation, which is known to reduce mineral sediment introduction (Allen, 2000; Darke and Megonigal, 2003). Results therefore support increased accumulation rates of anthropogenic marshes versus coves, being due to the tendency for marsh to build elevation via the combination of clastic sediment trapping and in-situ organic production. Anthropogenic open-water coves appear to trap more inorganic clastic sediment than their anthropogenic marsh counterparts (Fig. 12D). This is consistent with observations from polders, where inorganic sedimentation prior to emergent vegetation establishment can far exceed that observed on vegetated marsh platforms due to greater tidal inundation and accommodation space within newly sheltered intertidal mudflats (Hofstede, 2003). The exception to this is the most recently developed fringing marsh at Vanderburgh Cove (VBM1), where average mineral accumulation rates of between 0.5 and $0.6 \mathrm{~g} \mathrm{~cm}^{-2} \mathrm{yr}^{-1}$ are similar to those observed within open-water regions of the cove (VBC), and the open-water Tivoli South Bay (TVS) site. Successive aerial photos show that this fringing marsh has developed rapidly since 1978 (Supp. Fig. 1). In contrast, we observe the lowest rate of mineral accumulation among the anthropogenic marshes at Tivoli North Bay (TVN, $0.2 \mathrm{~g} \mathrm{~cm}^{-2} \mathrm{yr}^{-1}$ ). Tivoli North Marsh (TVN) is also the earliest established of our anthropogenic marshes, with 1932 topographic maps showing similar marsh extent to today (Supp. Fig. 2). It is therefore likely that Tivoli North Marsh has accreted sufficiently that high trapping rates of incoming suspended sediment are limited to marsh locations proximal to channels, and that in-situ organic production accounting for the bulk of accretion in much of the marshes' interior. Median mineral accumulation rates for the less sheltered Esopus (ESP) and Stockport (SPM) marshes are both $\sim 0.3 \mathrm{~g} \mathrm{~cm}^{-2} \mathrm{yr}^{-1}$, which is less than observed in the most recently developing Vanderburgh marsh system, and greater than rates for the more established marshes at Tivoli North.

We can apply a basic model that assumes average clastic sediment accumulation rates of $0.3 \mathrm{~g} \mathrm{~cm}^{-2} \mathrm{yr}^{-1}$ for anthropogenic marshes and $0.6 \mathrm{~g} \mathrm{~cm}^{-2} \mathrm{yr}^{-1}$ to anthropogenic tidal flats to derive a rough approximation of annual net inorganic sediment trapping (i.e. total deposition minus erosion) within these modified areas. While this is a simplification that does not account for heterogeneity of marsh accretion beyond that captured by our core transects, it gives a rough appraisal of the role of sediment storage within post-industrially developed marshes. We approximate $0.07 \mathrm{Mt} \mathrm{yr}^{-1}$ of net clastic accumulation in newly developed marshes based on these simplifications, which is equivalent to roughly $6 \%$ of the present Hudson River sediment load (Ralston et al., 2020).

\subsection{Conceptual Model of Marsh Creation}

Efforts to create or restore marshes are hampered by the decadal timescales required to evaluate the success or failure of projects. While several studies have documented deleterious effects to extant marshes from hydrodynamic alteration (e.g., Delgado et al., 2013) , we know of no other study that documents the widespread and inadvertent creation of tidal marsh via such human actions. However, there is a growing appreciation for marsh expansion in the Northeast US following European colonization in the 1600s (Braswell et al., 2020).

Sediment core data and historical maps and aerial photos from the sites presented here provide examples of the developmental stages from shallow embayment to mudflat to emergent marsh. These observations can be a resource for ongoing and future marsh creation projects, which can be monitored and modified as needed based on comparison with these historical, if inadvertent, successes in marsh creation. For example, the anthropogenic marsh observations presented here provide bounds for expected clastic and organic sediment accumulation rates during marsh creation and development. 
These results highlight that rapid wetland development is possible even under micro-tidal conditions and in a post-glacial region generally considered to exhibit relatively low sediment yields. The onset and development of marshes in the Hudson in the late $19^{\text {th }}$ and early $20^{\text {th }}$ century coincided with a period of reforestation across the Northeast US (Foster, 1992; Kudish, 2000) and dam construction. Dredging and channelization of the Lower Hudson's tidal channel reduced flooding from discharge events (Ralston et al. 2019). These factors likely reduced sediment inputs to the estuary and delivery to the wetlands, and yet marsh growth was extensive and rapid.

Using the anthropogenic marshes at Stockport and Tivoli North as representative cases, we characterize the phases of marsh development at each of these sites. Prior to anthropogenic shoreline changes, shallow, subtidal sand shoals occupied these locations (Sritrairat et al., 2012). The water depths under pre-anthropogenic alterations were likely relatively stable, with deposition of coarse sediment from the Hudson and local tributaries balanced by increased accommodation space due to long-term sea level rise and erosion during periods of elevated wind, tidal energy, and river discharge. The emplacement of dredge spoils at Stockport and railroad construction at Tivoli reduced the hydrodynamic energy within the newly protected coves at each site. This transition in energy conditions was marked by a fining of the depositional sediment, an increase in clastic sediment accumulation rate, and a modest increase in accumulation of particulate organic material. Flood-dominant tidal fluxes from the Hudson River into these coves (Benoit et al., 1999), provided abundant clastic sediment to allow for rapid aggradation of the bed during this phase, which likely resembled low intertidal habitat present today at Vanderburgh Cove (e.g. VBC4). It is worth emphasizing that this phase of aggradation is a key step in the subsequent establishment of emergent marsh vegetation, which has a narrow range of tidal elevation at which it can establish (Odum, 1988; Redfield, 1972). For example, in 2014 lidar data at Vanderburgh Cove, the interquartile range of the elevation (NAVD88) of the boundary between horizontally expanding emergent marsh and low intertidal vegetation (e.g. Nuphar advena) is 0.05 to $0.13 \mathrm{mASL}$ (NOAA 2014), which reflects the lower end of the elevation range at which Typha begins to colonize at this site. For reference, mean high water is $1.2 \mathrm{mASL}$ at Turkey Point tide gauge (NOAA 8518962), $16 \mathrm{~km}$ landward from this site.

Over decades, clastic sediment accumulation decreased water depth and allowed for establishment of shallow intertidal vegetation such as Nuphar advena, which has roots and corms that contribute to further aggradation of the substrate. Abundant Nuphar corms were observed in core VBC4 at Vanderburgh Cove. Cores from marshes showed increased rootlet density characteristic of the transition to emergent marsh and colonization by Typha and associated vegetation. A schematic diagram of this mature stage of transition is presented in Fig. 14 showing the roles of human-made structures in reducing hydrodynamic energy and tides in delivering sediment to these sheltered areas. Root density in split cores and LOI indicate the onset of emergent tidal marsh. Root density increased above $100 \mathrm{~cm}$ depth in cores from Tivoli North and dated to approximately 1910, compared to a depth of $40 \mathrm{~cm}$ at Stockport Marsh and a corresponding age of approximately 1975 based on aerial photographs and ${ }^{137} \mathrm{Cs}$ chronology (Fig. 6 and Fig. 7). The discrepancy in root onset depth reflects the relative maturity of these two systems and with Stockport Marsh being younger and at a lower elevation in the tidal frame (Supp. Fig. 4).

Core locations were not surveyed relative to a global datum, but available lidar data provides a means to evaluate differences in elevation between Tivoli and Stockport. Lidar data suffers from inaccuracy in dense marsh vegetation (Buffington et al., 2016). We evaluated offsets between survey-derived and lidar-derived elevations of the marsh platform at 26 points in Tivoli North Bay. We found a $0.30 \mathrm{~m}$ offset (standard deviation $=0.09 \mathrm{~m}$ ), with lidar values higher than surveyed elevations due to dense vegetation impeding lidar penetration and reflection. Uncorrected lidar-derived elevation values along core 
transects yielded a median elevation of the marsh platform at Tivoli North of roughly $1.25 \mathrm{mASL}$, versus 0.75 mASL at Stockport Marsh (NYSDEC, 2012; Supp. Fig. 4). Assuming that the lidar versus surveyed offset is similar at both marshes, Stockport Marsh is roughly $0.5 \mathrm{~m}$ lower than Tivoli North, reflecting its more recent transition from mudflat to marsh. It continues to rapidly trap clastic sediment at twice the rate observed at Tivoli North (Fig. 12), and therefore is more representative of a mineralogenic marsh (Allen, 2000). Conversely, Tivoli North Marsh has accreted sufficiently to reduce tidal inundation at its interior and has transitioned to a more organogenic and mature marsh.

\subsection{Estuarine tidal versus terrigenous fluvial sediment supply}

Most of the sites in this study were located at tributary mouths, raising the question to what extent marshes source their sediment from the main body of the estuary versus a local fluvial source. Benoit et al. (1999) found that tidal sediment contributions from the Hudson over four tidal cycles at Tivoli South Bay were only able to explain roughly $30 \%$ of their averaged rate of $\mathrm{Pb}$-210-derived accumulation rates there. However, this percentage increases to roughly $55 \%$ when applying our more recent ${ }^{137} \mathrm{Cs}$ derived and slightly lower accumulation rates of $0.6 \mathrm{~cm} / \mathrm{yr}$, and $100 \%$ when applying earlier average flooddominated Hudson contributions to Tivoli South Bay measured over eight separate tidal cycles by Goldhammer and Findlay (1988).

Using a regional value for watershed sediment yield of $60 \mathrm{~T} \mathrm{~km}^{-2} \mathrm{yr}^{-1}$ (Ralston et al., 2020 PREPRINT) we estimate the likely sediment discharge of Sawkill Creek to TVS since the railroad partially enclosed the cove in 1851 . This approach suggests that Sawkill Creek could account for up to $65 \%$ of the sediment that has accumulated in Tivoli South Bay if all of the watershed's sediment were trapped within the cove. Perfect trapping is unlikely considering that storm flows deliver a disproportionate amount of sediment, and storm flows have low residence time in side embayments, with reduced sediment trapping efficiency. Therefore, tidal delivery of sediments from the Hudson's main stem to the cove likely supplies most of the accumulated sediment. The range of solutions to this two end-member problem suggests that further study is needed to deconvolve the relative importance of local terrestrialderived versus estuarine sediment in wetland accretion. However, successful marsh establishment at Stockport Marsh, where there is no direct input of tributary sediment suggests that the estuary alone provides sufficient sediment inputs to rapidly develop emergent tidal wetlands in the Hudson.

It is possible that average rates of deposition over the last few decades via ${ }^{210} \mathrm{~Pb}$ and ${ }^{137} \mathrm{Cs}$ chronologies could over predict current rates of trapping at sites like Tivoli South Bay, since current trapping efficiencies for its predominantly tidal flat conditions are potentially less than infilling rates when depths were significantly greater. Analogously, the dredged channels of Jamaica Bay have average rates of infilling since the $1954{ }^{137} \mathrm{Cs}$ onset of 1.4 to $1.6 \mathrm{~cm} / \mathrm{yr}$ (Bopp et al., 1993), more than twice that observed in the shallower, predominantly tidal flat environments of Tivoli South and Vanderburgh Cove (Fig. 13). These enhanced rates of trapping in dredged channels of Jamaica Bay starkly contrast with the five times slower rates of accumulation on the neighboring marsh platform the Jamaica Bay Marsh, where organic content is also higher (Fig. 13). Increased trapping in dredged channels of Jamaica Bay likely contributes to the reduced sediment supply for marshes there that has resulted in lateral erosion and marsh loss in recent decades (Hartig et al., 2002). This is in stark contrast to results presented herein from anthropogenic marshes on the Hudson, which have either remained stable or grown in extent over the same interval. High accumulation rates within these anthropogenic tidal marshes reflect their more recent and rapid development from lower elevations. Longer duration hydroperiods, sheltered conditions, and a readily available sediment supply have allowed them to accrete rapidly towards equilibrium with modern sea level. 


\section{Conclusion}

649 We used sediment cores and historical evidence from maps, charts, and aerial photos to reconstruct the developmental histories of six tidal wetland complexes in the Hudson River Estuary. Five of the sites are representative of a suite of anthropogenic shoreline modifications that are widespread in the tidal river, especially in its uppermost $100 \mathrm{~km}$. Iona Island Marsh was used as a reference site, as emergent marsh there long predates industrial modification of the Hudson's channel and coastlines. We found that newly sheltered anthropogenic marshes and coves accumulate clastic sediment up to 10-30 times faster than the long-established reference site. A geospatial analysis of all extant wetlands in the Hudson River Estuary indicated that more than half of the emergent marsh has grown in the last 120 years, with an estimated net clastic sediment accumulation that constitutes roughly $6 \%$ of the annual suspended sediment load for the Hudson. Anthropogenic wetland/cove sites represent different phases of emergent marsh development, including tidal mudflat (e.g. Tivoli South Bay), rapidly growing tidal marsh (e.g. Vanderburgh and Stockport Marshes), and mature marsh (e.g. Tivoli North Bay). Together, these sites offer examples of expected environmental transitions for future tidal marsh creation projects. The work also helps to highlight that freshwater tidal wetlands can be created relatively quickly along microtidal estuaries in regions generally considered to have low sediment delivery to the ocean similar to the Hudson River in the Northeast US.

\section{Acknowledgements}

The authors gratefully acknowledge the guidance of a multi-stakeholder advisory committee and the hospitality provided by Norrie Point Environmental Center. This work was sponsored by the National Estuarine Research Reserve System Science Collaborative, which is funded by the National Oceanic and Atmospheric Administration and managed by the University of Michigan Water Center (NAI4NOS4190145). This project was supported by Grant or Cooperative Agreement No. G12AC00001 from the U.S. Geological Survey and Department of Interior Northeast Climate Adaptation Science Center fellowships for Caroline Ladlow and Brian Yellen. Its contents are solely the responsibility of the authors and do not necessarily represent the views of the Northeast Climate Adaptation Science Center or the USGS. Waverly Lau received funding in the form of a Polgar Fellowship from the Hudson River Foundation. The authors thank Frances Griswold, Mark Butler, Julia Casey, Kyra Simmons, and Max

\section{Data Availability Statement}

680 Data from sediment cores that were collected in association with this manuscript are archived 681 here: https://doi.org/10.7275/dh3v-0x33

\section{CITATIONS}

Abood, K.A., 1974. Circulation in the Hudson Estuary. Annals of the New York Academy of Sciences 250, 39-111. https://doi.org/10.1111/j.1749-6632.1974.tb43895.x

Ahn, K.-H., Steinschneider, S., 2018. Time-varying suspended sediment-discharge rating curves to estimate climate impacts on fluvial sediment transport. Hydrological Processes 32, 102-117. https://doi.org/10.1002/hyp.11402 coastal belt of Bangladesh. CRC Press. 
Allen, J.R.L., 2000. Morphodynamics of Holocene salt marshes: a review sketch from the Atlantic and Southern North Sea coasts of Europe. Quaternary Science Reviews 19, 1155-1231. https://doi.org/10.1016/S0277-3791(99)00034-7

Appleby, P.G., Oldfield, F., 1978. The calculation of lead-210 dates assuming a constant rate of supply of unsupported $210 \mathrm{~Pb}$ to the sediment. Catena $5,1-8$.

Armstrong, W.H., Collins, M.J., Snyder, N.P., 2012. Increased Frequency of Low-Magnitude Floods in New England1. JAWRA Journal of the American Water Resources Association 48, 306-320. https://doi.org/10.1111/j.1752-1688.2011.00613.x

Benoit, G., Wang, E.X., Nieder, W.C., Levandowsky, M., Breslin, V.T., 1999. Sources and history of heavy metal contamination and sediment deposition in Tivoli South Bay, Hudson River, New York. Estuaries 22, 167-178.

Biggs, D.A., 2012. Quagmire: Nation-building and nature in the Mekong Delta. University of Washington Press.

Blum, M.D., Roberts, H.H., 2009. Drowning of the Mississippi Delta due to insufficient sediment supply and global sea-level rise. Nature Geoscience 2, 488-491.

Boesch, D.F., Turner, R.E., 1984. Dependence of fishery species on salt marshes: The role of food and refuge. Estuaries 7, 460-468. https://doi.org/10.2307/1351627

Boorman, L., Hazelden, J., Boorman, M., 2002. New Salt Marshes for Old - Salt Marsh Creation and Management 11.

Bopp, R.F., Simpson, H.J., Chillrud, S.N., Robinson, D.W., 1993. Sediment-derived chronologies of persistent contaminants in Jamaica Bay, New York. Estuaries 16, 608-616.

Bouma, T.J., Vries, M.B.De., Low, E., Kusters, L., Herman, P.M.J., Tánczos, I.C., Temmerman, S., Hesselink, A., Meire, P., Regenmortel, S. van., 2005. Flow hydrodynamics on a mudflat and in salt marsh vegetation: identifying general relationships for habitat characterisations. Hydrobiologia 540, 259-274. https://doi.org/10.1007/s10750-004-7149-0

Brain, M.J., Kemp, A.C., Hawkes, A.D., Engelhart, S.E., Vane, C.H., Cahill, N., Hill, T.D., Donnelly, J.P., Horton, B.P., 2017. Exploring mechanisms of compaction in salt-marsh sediments using Common Era relative sea-level reconstructions. Quaternary Science Reviews 167, 96-111. https://doi.org/10.1016/j.quascirev.2017.04.027

Braswell, A.E., Heffernan, J.B., Kirwan, M.L., (2020). How old are marshes on the East Coast, USA? Complex patterns in wetland age within and among regions. Geophysical Research Letters n/a, e2020GL089415. https://doi.org/10.1029/2020GL089415

Brin, L.D., Valiela, I., Goehringer, D., Howes, B., 2010. Nitrogen interception and export by experimental salt marsh plots exposed to chronic nutrient addition. Marine Ecology Progress Series 400, 3-17. https://doi.org/10.3354/meps08460

Broome, S.W., Craft, C.B., Burchell, M.R., 2019. Chapter 22 - Tidal Marsh Creation, in: Perillo, G.M.E., Wolanski, E., Cahoon, D.R., Hopkinson, C.S. (Eds.), Coastal Wetlands. Elsevier, pp. 789-816. https://doi.org/10.1016/B978-0-444-63893-9.00022-8

Buffington, K.J., Dugger, B.D., Thorne, K.M., Takekawa, J.Y., 2016. Statistical correction of lidar-derived digital elevation models with multispectral airborne imagery in tidal marshes. Remote Sensing of Environment 186, 616-625. https://doi.org/10.1016/j.rse.2016.09.020

Cahoon, D.R., Reed, D.J., Day, J.W., 1995. Estimating shallow subsidence in microtidal salt marshes of the southeastern United States: Kaye and Barghoorn revisited. Marine Geology 128, 1-9. https://doi.org/10.1016/0025-3227(95)00087-F

Chen, Z., Saito, Y., Kanai, Y., Wei, T., Li, L., Yao, H., Wang, Z., 2004. Low concentration of heavy metals in the Yangtze estuarine sediments, China: a diluting setting. Estuarine, Coastal and Shelf Science 60, 91-100. 
Chou, C., Peteet, D., 2009. Macrofossil evidence for Middle to Late Holocene vegetation shifts at lona Island Marsh, Hudson Valley, NY. Final Report of the Tibor T. Polgar Fellowship Program.

Cochard, R., Ranamukhaarachchi, S.L., Shivakoti, G.P., Shipin, O.V., Edwards, P.J., Seeland, K.T., 2008. The 2004 tsunami in Aceh and Southern Thailand: a review on coastal ecosystems, wave hazards and vulnerability. Perspectives in Plant Ecology, Evolution and Systematics 10, 3-40.

Collins, M.J., Miller, D., 2012. Upper Hudson River Estuary (usa) Floodplain Change Over the 20th Century. River Research and Applications 28, 1246-1253. https://doi.org/10.1002/rra.1509

Cook, T.L., Yellen, B.C., Woodruff, J.D., Miller, D., 2015. Contrasting human versus climatic impacts on erosion. Geophysical Research Letters 42, 6680-6687. https://doi.org/10.1002/2015GL064436

Craft, C., Broome, S., Campbell, C., 2002. Fifteen Years of Vegetation and Soil Development after Brackish-Water Marsh Creation. Restoration Ecology 10, 248-258. https://doi.org/10.1046/j.1526-100X.2002.01020.x

Crosby, S.C., Sax, D.F., Palmer, M.E., Booth, H.S., Deegan, L.A., Bertness, M.D., Leslie, H.M., 2016. Salt marsh persistence is threatened by predicted sea-level rise. Estuarine, Coastal and Shelf Science 181, 93-99. https://doi.org/10.1016/j.ecss.2016.08.018

Croudace, I.W., Rindby, A., Rothwell, R.G., 2006. ITRAX: description and evaluation of a new multifunction X-ray core scanner. Geological Society, London, Special Publications 267, 51-63.

Darke, A.K., Megonigal, J.P., 2003. Control of sediment deposition rates in two mid-Atlantic Coast tidal freshwater wetlands. Estuarine, Coastal and Shelf Science 57, 255-268. https://doi.org/10.1016/S0272-7714(02)00353-0

Dean, W.E., 1974. Determination of carbonate and organic matter in calcareous sediments and sedimentary rocks by loss on ignition; comparison with other methods. Journal of Sedimentary Research 44, 242-248.

Delgado, P., Hensel, P.F., Swarth, C.W., Ceroni, M., Boumans, R., 2013. Sustainability of a Tidal Freshwater Marsh Exposed to a Long-term Hydrologic Barrier and Sea Level Rise: A Short-term and Decadal Analysis of Elevation Change Dynamics. Estuaries and Coasts 36, 585-594. https://doi.org/10.1007/s12237-013-9587-2

Emery, K.O., Wigley, R.L., Rubin, M., 1965. A Submerged Peat Deposit Off the Atlantic Coast of the United States1. Limnology and Oceanography 10, R97-R102. https://doi.org/10.4319/lo.1965.10.suppl2.r97

Ewers Lewis, C.J., Baldock, J.A., Hawke, B., Gadd, P.S., Zawadzki, A., Heijnis, H., Jacobsen, G.E., Rogers, K., Macreadie, P.I., 2019. Impacts of land reclamation on tidal marsh 'blue carbon' stocks. Science of The Total Environment 672, 427-437. https://doi.org/10.1016/j.scitotenv.2019.03.345

Faber, M., 2002. Soil survey of Dutchess County, New York.

FitzGerald, D.M., Hughes, Z., 2019. Marsh Processes and Their Response to Climate Change and SeaLevel Rise. Annual Review of Earth and Planetary Sciences 47, 481-517. https://doi.org/10.1146/annurev-earth-082517-010255

Foster, D.R., 1992. Land-Use History (1730-1990) and Vegetation Dynamics in Central New England, USA. Journal of Ecology 80, 753-771. https://doi.org/10.2307/2260864

French, J.R., Spencer, T., 1993. Dynamics of sedimentation in a tide-dominated backbarrier salt marsh, Norfolk, UK. Marine Geology 110, 315-331. https://doi.org/10.1016/0025-3227(93)90091-9

Gedan, K.B., Kirwan, M.L., Wolanski, E., Barbier, E.B., Silliman, B.R., 2011. The present and future role of coastal wetland vegetation in protecting shorelines: answering recent challenges to the paradigm. Climatic Change 106, 7-29. https://doi.org/10.1007/s10584-010-0003-7

Gu, J., Luo, M., Zhang, X., Christakos, G., Agusti, S., Duarte, C.M., Wu, J., 2018. Losses of salt marsh in China: Trends, threats and management. Estuarine, Coastal and Shelf Science 214, 98-109. https://doi.org/10.1016/j.ecss.2018.09.015 
Hartig, E.K., Gornitz, V., Kolker, A., Mushacke, F., Fallon, D., 2002. Anthropogenic and climate-change impacts on salt marshes of Jamaica Bay, New York City. Wetlands 22, 71-89.

Hilfinger IV, M.F., Mullins, H.T., Burnett, A., Kirby, M.E., 2001. A 2500 year sediment record from Fayetteville Green Lake, New York: evidence for anthropogenic impacts and historic isotope shift. Journal of Paleolimnology 26, 293-305. https://doi.org/10.1023/A:1017560300681

Hofstede, J.L.A., 2003. Integrated management of artificially created salt marshes in the Wadden Sea of Schleswig-Holstein, Germany. Wetlands Ecology and Management 11, 183-194. https://doi.org/10.1023/A:1024248127037

Kemp, A.C., Hill, T.D., Vane, C.H., Cahill, N., Orton, P.M., Talke, S.A., Parnell, A.C., Sanborn, K., Hartig, E.K., 2017. Relative sea-level trends in New York City during the past 1500 years. The Holocene 27, 1169-1186.

Kirwan, M.L., Murray, A.B., Donnelly, J.P., Corbett, D.R., 2011. Rapid wetland expansion during European settlement and its implication for marsh survival under modern sediment delivery rates. Geology 39, 507-510. https://doi.org/10.1130/G31789.1

Kneib, R.T., 1997. The role of tidal marshes in the ecology of estuarine nekton. Oceanography and Marine Biology 35, 163-220.

Knutson, P.L., Brochu, R.A., Seelig, W.N., Inskeep, M., 1982. Wave damping inSpartinaalterniflora marshes. Wetlands 2, 87-104. https://doi.org/10.1007/BF03160548

Kudish, M., 2000. The Catskill forest: a history. Purple Mountain Press.

LaSalle, M.W., Landin, M.C., Sims, J.G., 1991. Evaluation of the flora and fauna of aSpartina alterniflora marsh established on dredged material in Winyah Bay, South Carolina. Wetlands 11, 191-208. https://doi.org/10.1007/BF03160849

Lechêne, A., Boët, P., Laffaille, P., Lobry, J., 2018. Nekton communities of tidally restored marshes: A whole-estuary approach. Estuarine, Coastal and Shelf Science 207, 368-382. https://doi.org/10.1016/j.ecss.2017.08.038

Long, A.J., Waller, M.P., Stupples, P., 2006. Driving mechanisms of coastal change: Peat compaction and the destruction of late Holocene coastal wetlands. Marine Geology 225, 63-84. https://doi.org/10.1016/j.margeo.2005.09.004

Mariotti, G., Elsey-Quirk, T., Bruno, G., Valentine, K., n.d. Mud-associated organic matter and its direct and indirect role in marsh organic matter accumulation and vertical accretion. Limnology and Oceanography n/a. https://doi.org/10.1002/Ino.11475

McHale, M.R., Siemion, J., 2014. Turbidity and suspended sediment in the upper Esopus Creek watershed, Ulster County, New York. US Geological Survey.

Meade, R.H., 1982. Sources, Sinks, and Storage of River Sediment in the Atlantic Drainage of the United States. The Journal of Geology 90, 235-252. https://doi.org/10.1086/628677

Meier, D., 2004. Man and environment in the marsh area of Schleswig-Holstein from Roman until late Medieval times. Quaternary International, Geological processes and human interaction on the German North Sea coast 112, 55-69. https://doi.org/10.1016/S1040-6182(03)00065-X

Miller, D., Ladd, J., Nieder, W.C., 2006. Channel morphology in the Hudson River Estuary: Historical changes and opportunities for restoration, in: American Fisheries Society Symposium. American Fisheries Society, p. 29.

Minello, T.J., Rozas, L.P., Baker, R., 2012. Geographic Variability in Salt Marsh Flooding Patterns may Affect Nursery Value for Fishery Species. Estuaries and Coasts 35, 501-514. https://doi.org/10.1007/s12237-011-9463-x

Morris, J.T., Barber, D.C., Callaway, J.C., Chambers, R., Hagen, S.C., Hopkinson, C.S., Johnson, B.J., Megonigal, P., Neubauer, S.C., Troxler, T., Wigand, C., 2016. Contributions of organic and inorganic matter to sediment volume and accretion in tidal wetlands at steady state. Earth's Future 4, 110-121. https://doi.org/10.1002/2015EF000334 
Neckles, H.A., Dionne, M., Burdick, D.M., Roman, C.T., Buchsbaum, R., Hutchins, E., 2002. A Monitoring Protocol to Assess Tidal Restoration of Salt Marshes on Local and Regional Scales. Restoration Ecology 10, 556-563. https://doi.org/10.1046/j.1526-100X.2002.02033.x

Nelson, J.L., Zavaleta, E.S., 2012. Salt Marsh as a Coastal Filter for the Oceans: Changes in Function with Experimental Increases in Nitrogen Loading and Sea-Level Rise. PLOS ONE 7, e38558. https://doi.org/10.1371/journal.pone.0038558

Neubauer, S.C., 2008. Contributions of mineral and organic components to tidal freshwater marsh accretion. Estuarine, Coastal and Shelf Science 78, 78-88.

Nitsche, F.O., Ryan, W.B.F., Carbotte, S.M., Bell, R.E., Slagle, A., Bertinado, C., Flood, R., Kenna, T., McHugh, C., 2007. Regional patterns and local variations of sediment distribution in the Hudson River Estuary. Estuarine, Coastal and Shelf Science, Sedimentological and ecohydrological processes of Asian deltas: The Yangtze and the Mekong 71, 259-277. https://doi.org/10.1016/j.ecss.2006.07.021

Nolte, S., Koppenaal, E.C., Esselink, P., Dijkema, K.S., Schuerch, M., De Groot, A.V., Bakker, J.P., Temmerman, S., 2013. Measuring sedimentation in tidal marshes: a review on methods and their applicability in biogeomorphological studies. J Coast Conserv 17, 301-325. https://doi.org/10.1007/s11852-013-0238-3

Odum, W.E., 1988. Comparative ecology of tidal freshwater and salt marshes. Annual Review of Ecology and Systematics 19, 147-176.

Olsen, C.R., Simpson, H.J., Bopp, R.F., Williams, S.C., Peng, T.H., Deck, B.L., 1978. A geochemical analysis of the sediments and sedimentation in the Hudson Estuary. Journal of Sedimentary Research 48, 401-418. https://doi.org/10.1306/212F7496-2B24-11D7-8648000102C1865D

Olsson, K.S., 1981. Soil Survey of Orange County, New York. U.S. Department of Agriculture, Soil Conservation Service.

Palinkas, C.M., Engelhardt, K.A.M., 2016. Spatial and temporal patterns of modern ( $100 \mathrm{yr}$ ) sedimentation in a tidal freshwater marsh: Implications for future sustainability. Limnology and Oceanography 61, 132-148. https://doi.org/10.1002/Ino.10202

Panuzio, F.L., 1965. Lower Hudson River Siltation. Proceedings of the Federal InterAgency Sedimentation Conference. Agricultural Research Service 512-550.

Pederson, D.C., Peteet, D.M., Kurdyla, D., Guilderson, T., 2005. Medieval Warming, Little Ice Age, and European impact on the environment during the last millennium in the lower Hudson Valley, New York, USA. Quaternary Research 63, 238-249. https://doi.org/10.1016/j.yqres.2005.01.001

Pennington, W., Tutin, T.G., Cambray, R.S., Fisher, E.M., 1973. Observations on lake sediments using fallout 137 Cs as a tracer. Nature 242, 324.

Peteet, D.M., Nichols, J., Kenna, T., Chang, C., Browne, J., Reza, M., Kovari, S., Liberman, L., Stern-Protz, S., 2018. Sediment starvation destroys New York City marshes' resistance to sea level rise. PNAS 115, 10281-10286. https://doi.org/10.1073/pnas.1715392115

Ralston, D., Yellen, B., Woodruff, J., 2020. Watershed sediment supply and potential impacts of dam removals for an estuary [WWW Document]. Earth and Space Science Open Archive. https://doi.org/10.1002/essoar.10502519.1

Ralston, D.K., Geyer, W.R., Lerczak, J.A., 2008. Subtidal salinity and velocity in the Hudson River estuary: Observations and modeling. Journal of Physical Oceanography 38, 753-770.

Ralston, D.K., Talke, S., Geyer, W.R., Al-Zubaidi, H.A., Sommerfield, C.K., 2019. Bigger tides, less flooding: Effects of dredging on barotropic dynamics in a highly modified estuary. Journal of Geophysical Research: Oceans 124, 196-211.

Ralston, D.K., Warner, J.C., Geyer, W.R., Wall, G.R., 2013. Sediment transport due to extreme events: The Hudson River estuary after tropical storms Irene and Lee. Geophysical Research Letters 40, 5451-5455. https://doi.org/10.1002/2013GL057906 
Rayburn, J.A., Franzi, D.A., Knuepfer, P.L.K., 2007. Evidence from the Lake Champlain Valley for a later onset of the Champlain Sea and implications for late glacial meltwater routing to the North Atlantic. Palaeogeography, Palaeoclimatology, Palaeoecology, North American late-Quaternary meltwater and floods to the ocean: evidence and impact 246, 62-74. https://doi.org/10.1016/j.palaeo.2006.10.027

Redfield, A.C., 1972. Development of a New England salt marsh. Ecological monographs 42, 201-237. Schuerch, M., Spencer, T., Temmerman, S., Kirwan, M.L., Wolff, C., Lincke, D., McOwen, C.J., Pickering, M.D., Reef, R., Vafeidis, A.T., Hinkel, J., Nicholls, R.J., Brown, S., 2018. Future response of global coastal wetlands to sea-level rise. Nature 561, 231-234. https://doi.org/10.1038/s41586-0180476-5

Sholkovitz, E.R., 1976. Flocculation of dissolved organic and inorganic matter during the mixing of river water and seawater. Geochimica et Cosmochimica Acta 40, 831-845. https://doi.org/10.1016/0016-7037(76)90035-1

Smith, R.H., 1955. Experimental control of water chestnut (Trapa natans) in New York State. New York Fish and Game Journal 2, 173-193.

Spencer, T., Schuerch, M., Nicholls, R.J., Hinkel, J., Lincke, D., Vafeidis, A.T., Reef, R., McFadden, L., Brown, S., 2016. Global coastal wetland change under sea-level rise and related stresses: The DIVA Wetland Change Model. Global and Planetary Change 139, 15-30.

Squires, D.F., 1992. Quantifying anthropogenic shoreline modification of the Hudson River and Estuary from European contact to modern time. Coastal Management 20, 343-354. https://doi.org/10.1080/08920759209362183

Sritrairat, S., Peteet, D.M., Kenna, T.C., Sambrotto, R., Kurdyla, D., Guilderson, T., 2012. A history of vegetation, sediment and nutrient dynamics at Tivoli North Bay, Hudson Estuary, New York. Estuarine, Coastal and Shelf Science 102-103, 24-35. https://doi.org/10.1016/j.ecss.2012.03.003

Staszak, L.A., Armitage, A.R., 2012. Evaluating Salt Marsh Restoration Success with an Index of Ecosystem Integrity. Journal of Coastal Research 410-418. https://doi.org/10.2112/JCOASTRESD-12-00075.1

Tabak, N.M., Laba, M., Spector, S., 2016. Simulating the Effects of Sea Level Rise on the Resilience and Migration of Tidal Wetlands along the Hudson River. PLoS One 11. https://doi.org/10.1371/journal.pone.0152437

Temmerman, S., Govers, G., Wartel, S., Meire, P., 2003. Spatial and temporal factors controlling shortterm sedimentation in a salt and freshwater tidal marsh, Scheldt estuary, Belgium, SW Netherlands. Earth Surface Processes and Landforms 28, 739-755. https://doi.org/10.1002/esp.495

Thorne, K., MacDonald, G., Guntenspergen, G., Ambrose, R., Buffington, K., Dugger, B., Freeman, C., Janousek, C., Brown, L., Rosencranz, J., 2018. US Pacific coastal wetland resilience and vulnerability to sea-level rise. Science Advances 4, eaao3270.

Törnqvist, T.E., Jankowski, K.L., Li, Y.-X., González, J.L., 2020. Tipping points of Mississippi Delta marshes due to accelerated sea-level rise. Science Advances 6, eaaz5512. https://doi.org/10.1126/sciadv.aaz5512

Turner, R.E., Swenson, E.M., Milan, C.S., 2000. Organic and Inorganic Contributions to Vertical Accretion in Salt Marsh Sediments, in: Weinstein, M.P., Kreeger, D.A. (Eds.), Concepts and Controversies in Tidal Marsh Ecology. Springer Netherlands, Dordrecht, pp. 583-595. https://doi.org/10.1007/0306-47534-0_27

Warren, R.S., Fell, P.E., Rozsa, R., Brawley, A.H., Orsted, A.C., Olson, E.T., Swamy, V., Niering, W.A., 2002. Salt marsh restoration in Connecticut: 20 years of science and management. Restoration Ecology 10, 497-513. 
Wolters, M., Garbutt, A., Bakker, J.P., 2005. Salt-marsh restoration: evaluating the success of deembankments in north-west Europe. Biological Conservation 123, 249-268. https://doi.org/10.1016/j.biocon.2004.11.013

Wolters, S., Zeiler, M., Bungenstock, F., 2010. Early Holocene environmental history of sunken landscapes: pollen, plant macrofossil and geochemical analyses from the Borkum Riffgrund, southern North Sea. International Journal of Earth Sciences 99, 1707-1719.

Worzel, J.L., Drake, C.L., 1959. Structure Section Across the Hudson River at Nyack, N. Y., from Seismic Observations*. Annals of the New York Academy of Sciences 80, 1092-1105. https://doi.org/10.1111/j.1749-6632.1959.tb49282.x

Yan, R., Gao, J., Huang, J., 2019. Modelling the hydrological processes of a Chinese lowland polder and identifying the key factors using an improved PHPS model. Journal of Hydrology 578, 124083. https://doi.org/10.1016/j.jhydrol.2019.124083

Yellen, B., Steinschneider, S., 2019. GRADUAL RECOVERY FROM FLOOD DISTURBANCE RECORDED IN SEDIMENT CORES, in: Northeastern Section-54th Annual Meeting-2019. GSA.

Yozzo, D.J., Andersen, J.L., Cianciola, M.M., Nieder, W.C., Miller, D.E., Ciparis, S., McAvoy, J., 2005. Ecological Profile of the Hudson River National Estuarine Research Reserve 165.

Yozzo, D.J., Wilber, P., Will, R.J., 2004. Beneficial use of dredged material for habitat creation, enhancement, and restoration in New York-New Jersey Harbor. Journal of Environmental Management 73, 39-52. https://doi.org/10.1016/j.jenvman.2004.05.008 
951 Table 1: site characteristics for six wetland study sites within the Hudson River Estuary. Reported 952 catchment areas refer to the tributary catchment that enters the estuary at or near each marsh (see Fig. 953 1). Distance from the Battery, the southern tip of Manhattan Island in New York City is reported in km. 954 Dominant vegetative cover types within these wetlands include cattails (Typha angustifolia), Phragmites 955 australis, invasive water chestnut (Trapa Natans), and spatterdock (Nuphar advena).

\begin{tabular}{|c|c|c|c|c|c|c|}
\hline & Stockport & Esopus & Tiv. North & Tiv. South & Vanderburgh & Iona \\
\hline Site locus area (km2) & 0.25 & 0.11 & 1.45 & 1.05 & 0.36 & 0.49 \\
\hline Number of cores & 3 & 5 & 5 & 3 & 6 & 5 \\
\hline Catchment (km2) & 1340 & 1100 & 55 & 68 & 71 & 7.5 \\
\hline Dist. from Battery $(\mathrm{km})$ & 193 & 163 & 159.5 & 157 & 140 & 72 \\
\hline Dominant cover & Typha & Phrag/Typha & Typha & $\begin{array}{l}\text { Mudflat/ } \\
\text { Trapa }\end{array}$ & $\begin{array}{l}\text { Typha/Nuphar } \\
\text { /Trapa }\end{array}$ & Phrag/Typha \\
\hline $\begin{array}{l}\text { Avg Accumulation } \\
\text { Rate }(\mathrm{cm} / \mathrm{yr})\end{array}$ & 1.0 & 0.9 & 0.9 & 0.6 & 1.2 & 0.3 \\
\hline
\end{tabular}

956 


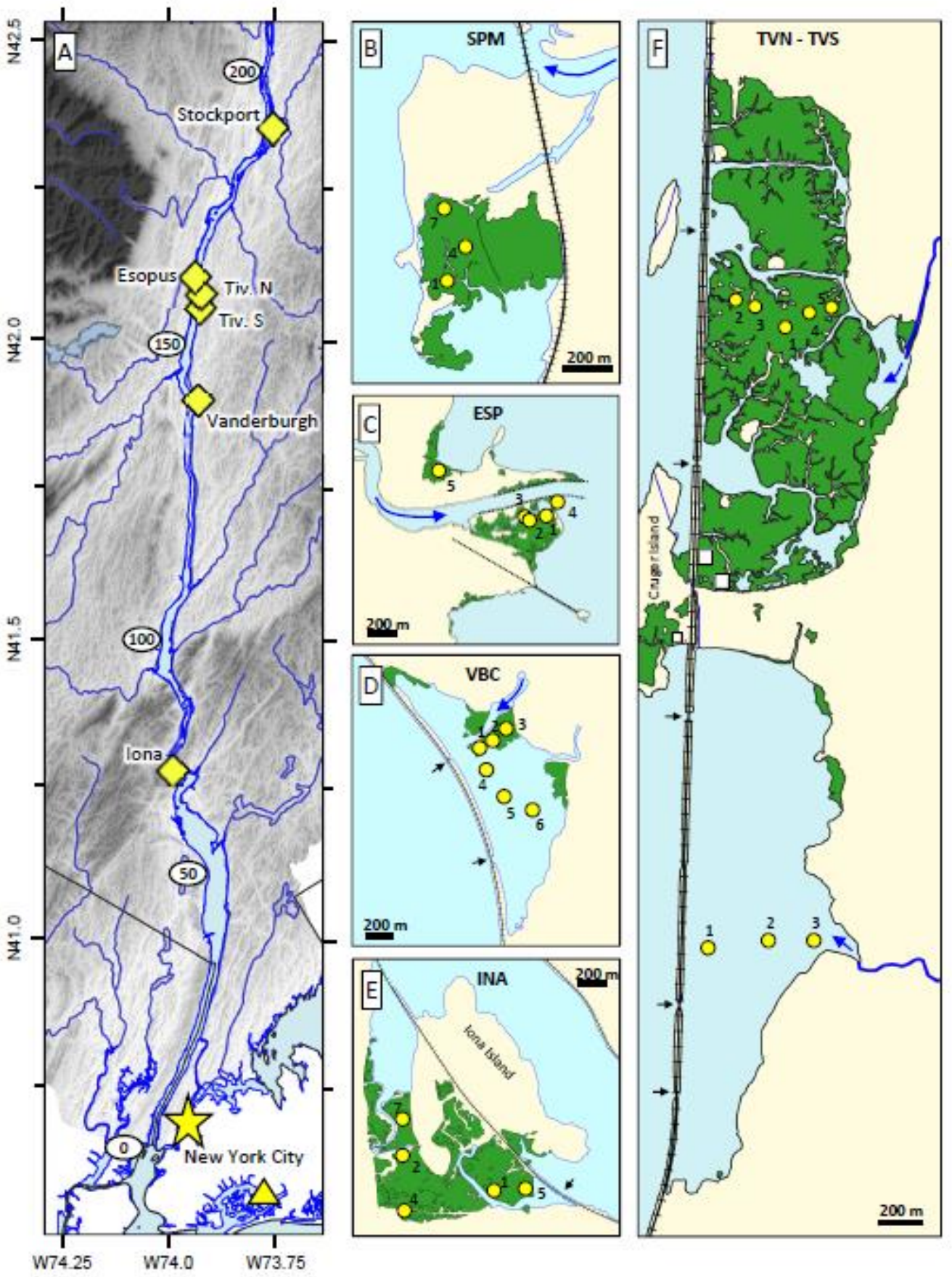

Fig. 1: Panel A depicts the six study sites (yellow diamonds) along the tidal Hudson River with New York City and Jamaica Bay (yellow triangle) at the mouth of the river. White ovals denote the distance from the Battery in kilometers. Panels B, C, D, E, F depict the location of emergent marsh in green at Stockport (SPM), Esopus delta (ESP), Vanderburg Cove (VBC), lona Island Marsh (INA), and Tivoli North (TVN) and South (TVS) Bays. White squares in panel $\mathrm{F}$ denote the locations of cores from Sritrairat et al. (2012). Yellow circles indicate the locations and core number of cores described in the text or in supplementary figures. Hardened structures (jetties and railroad berms) are shown in black, with black arrows indicating culvert locations. Significant tributary mouths are indicated with blue arrows. 

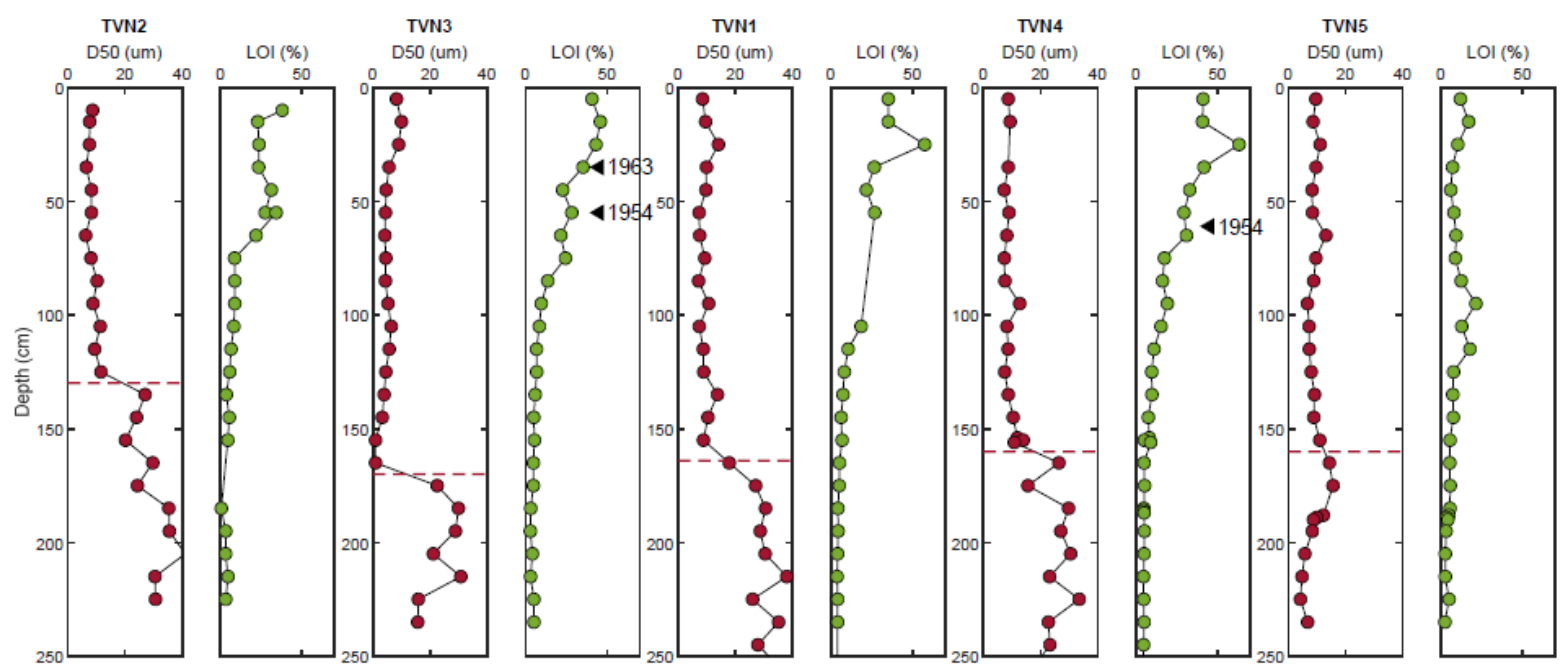

Fig. 2: Tivoli North core transect showing median grain size (red) and LOI (green) for cores from west to east. See Fig. 1 for locations. Dashed lines indicates a sudden drop in grain size in each core. Triangles denote depths of ${ }^{137} \mathrm{Cs}$ derived ages (TVN3 ${ }^{137} \mathrm{Cs}$ data shown in Fig. 3).
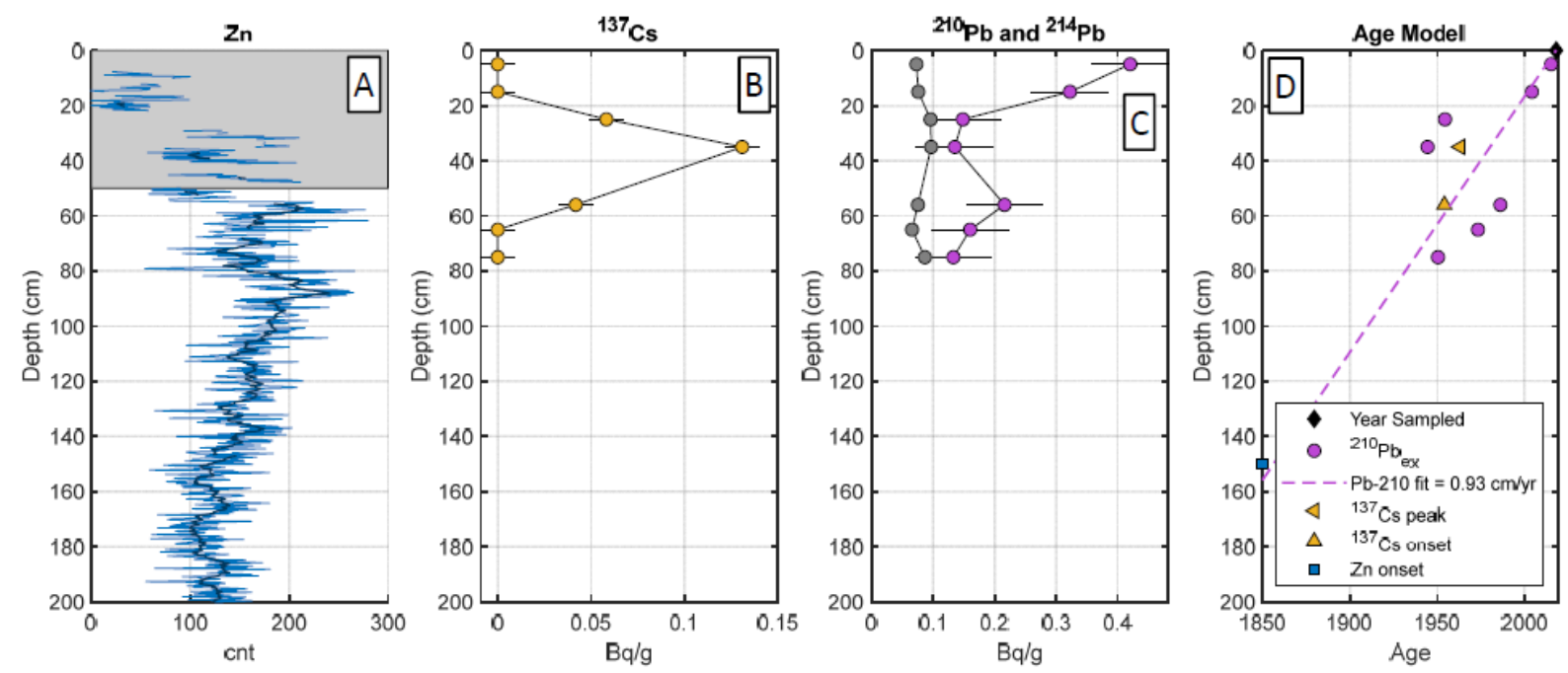

Fig. 3: Depth profiles from TVN3 Core including (A) zinc XRF counts, (B) ${ }^{137} \mathrm{Cs}$ and $(C){ }^{210} \mathrm{~Pb}$ and ${ }^{214} \mathrm{~Pb}$ activities. Error bars in $B$ and $C$ represent instrument measurement uncertainty. Lighter and darker blue lines in $A$ represent raw and $10 \mathrm{pt} \mathrm{low}$ pass filter of data and grey box denotes region of poor sampling due to root matter and highly porous surficial sediments. (D) Depth-to-age model based on 1954 onset and 1963 peak in ${ }^{137} \mathrm{Cs}$ (triangles), unsupported Pb-210 (magenta circles) and an assumed 1850 CE onset of elevated $\mathrm{Zn}$. Dashed line is $0.9 \mathrm{~cm} / \mathrm{yr}$ 


Zn (counts) $\quad$ D50 $(\mu \mathrm{m}) \quad$ LOI $(\%)$
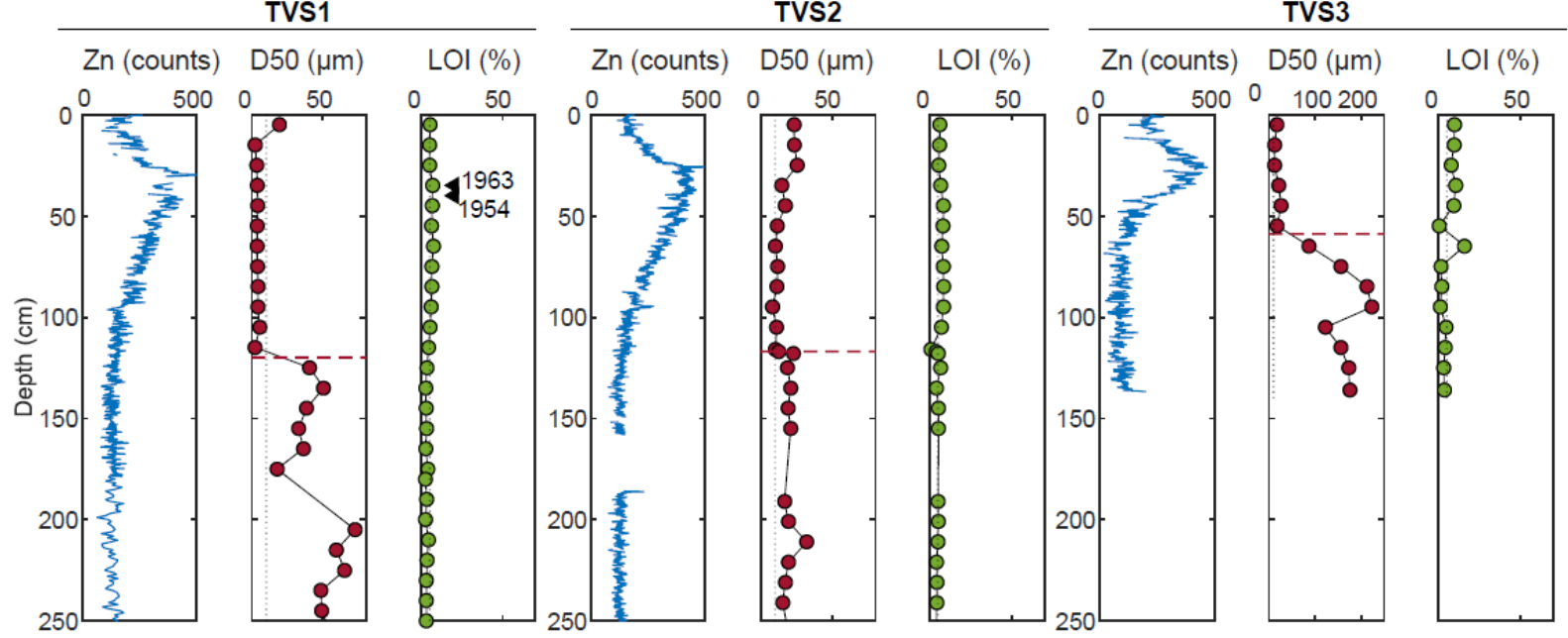

985

986

987

988

Fig. 4: Depth profiles of $\mathrm{Zn}$ (blue), median grain size (D50, red) and LOI (green) for the three core transect from Tivoli Bay South (see Fig. 1 for locations). Note axis for D50 in TVS3 is extended in order to include larger grain sizes observed at this location. A dotted vertical line at $5 \mu \mathrm{m}$ is provided for reference. Triangles denote depths of ${ }^{137} \mathrm{Cs}$ derived ages for TVS1.
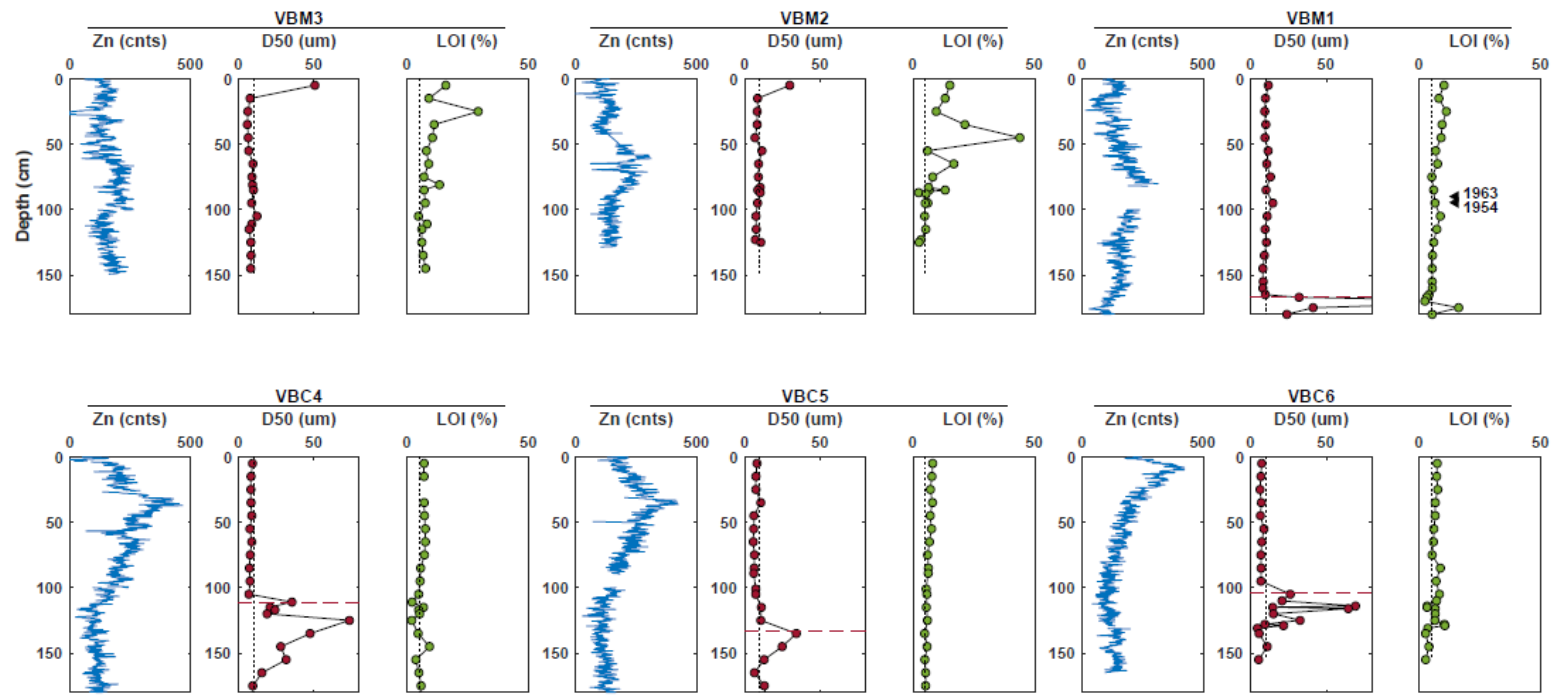

Fig. 5: Vanderburgh Cove depth profiles of Zn (blue), median grain size (D50, red) and LOI (green) for cores from the marsh (top panels) and open water/tidal flat (bottom panels), (see Fig. 1 for locations). Triangles in upper right LOI panel denote depths of ${ }^{137} \mathrm{Cs}$ derived ages for VBM1. 

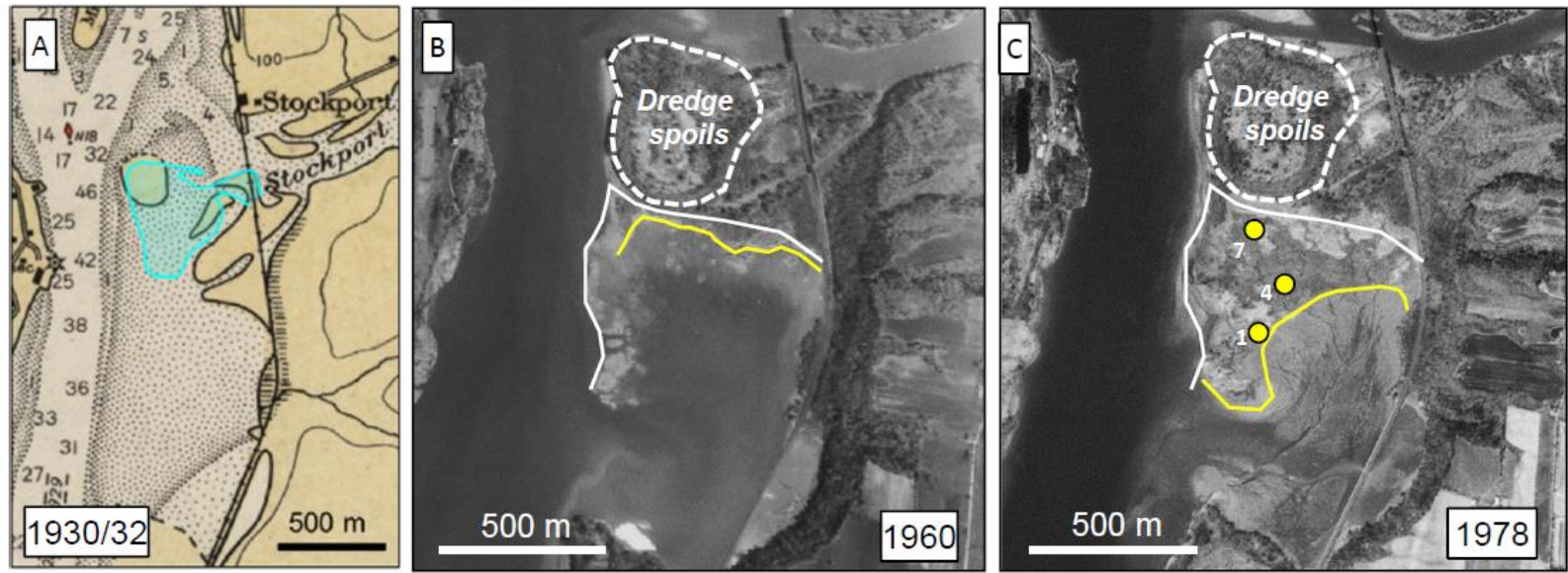

1000 1001 1002 1003 1004 1005 1006
Fig. 6: A historical chart (A) and aerial photos (B, C) depict the development of Stockport Marsh during the mid20th century. Panel A shows a portion of a 1930 nautical chart (US Coast and Geodetic Survey, 1930) with depths in feet $(1 \mathrm{ft}=0.3 \mathrm{~m})$. The shaded blue area depicts the outline of the island at the mouth of Stockport Creek in the 1932 chart revision (US Coast and Geodetic Survey, 1932). Panel B shows the development of a spit southward from the dredge spoils by 1960, with a white line indicating the edge of the interpreted shoreline. The yellow line indicates an interpreted marsh edge. Panel $C$ shows horizontal migration of the marsh over the former shoal area depicted in panel A, with core locations indicated for cores SPM1, SPM4, and SPM7.
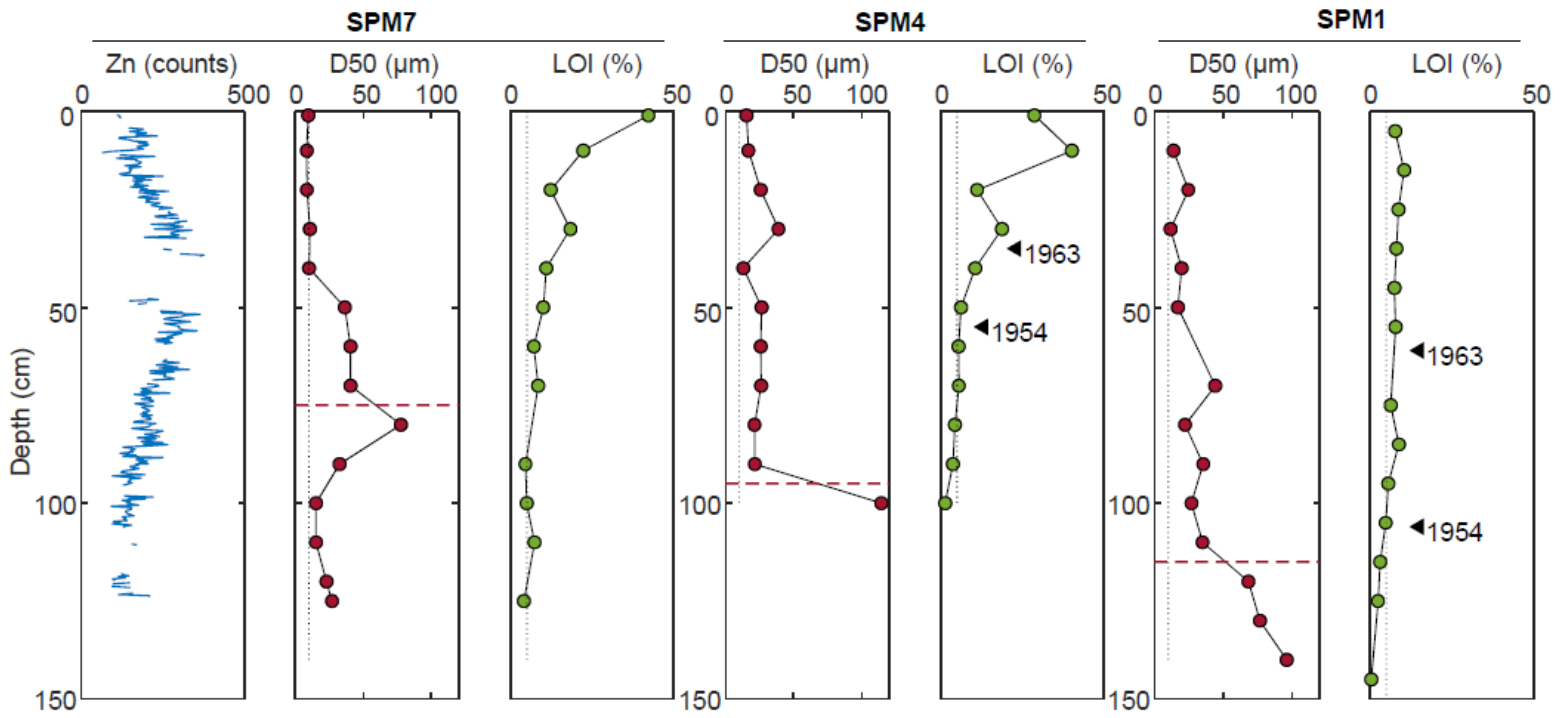

Fig. 7: Stockport Marsh depth profiles of Zn (blue), median grain size (D50, red) and LOI (green). Triangles in LOI panel denote depths of ${ }^{137} \mathrm{Cs}$ derived ages for SPM4 and SPM1. Dashed red line in grain size plots denotes sand-tomud transition. Zn profiles not shown for SPM4 and SPM1 due to poor data quality. 

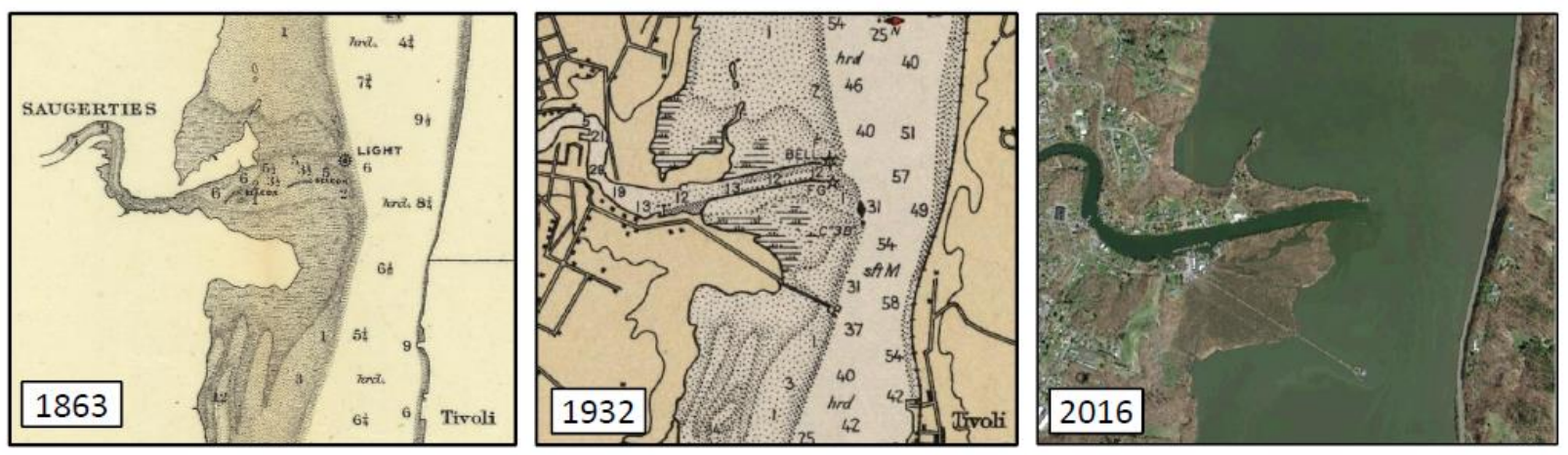

Fig. 8: Esopus Creek's delta at Saugerties, NY in 1863, 1932 and present as depicted in US Coast Survey nautical 1019 charts (US Coast Survey, 1863; US Coast and Geodetic Survey, 1932) and current aerial imagery (Google Earth, 2016). Note the appearance of fringing marsh in the 1932 map, followed by its more extensive development towards the modern.

1021
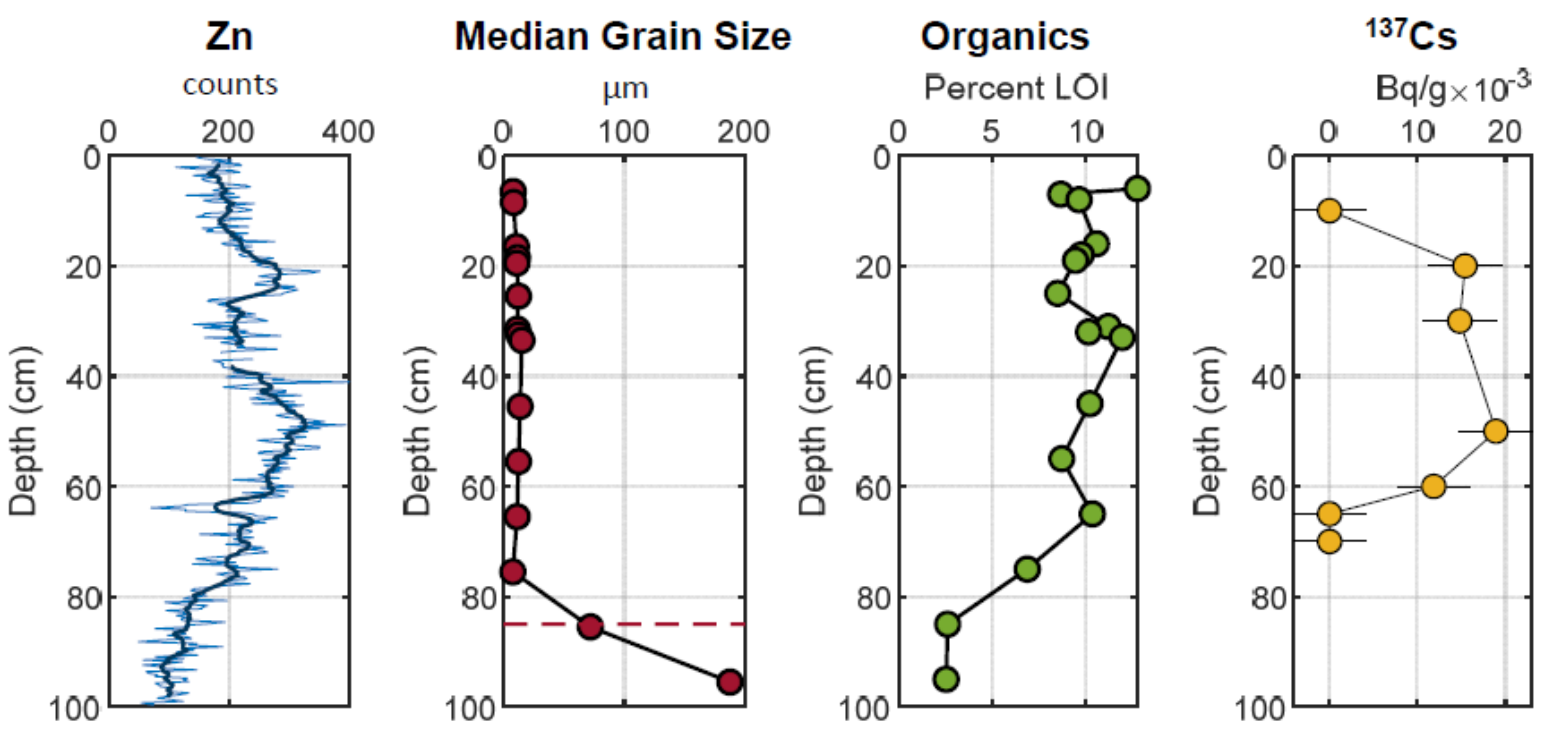

Fig. 9: ESP3 depth profiles of Zn (blue), median grain size (D50, red), LOI (green) and ${ }^{137} \mathrm{Cs}$ (error bars represent instrument measurement uncertainty). 


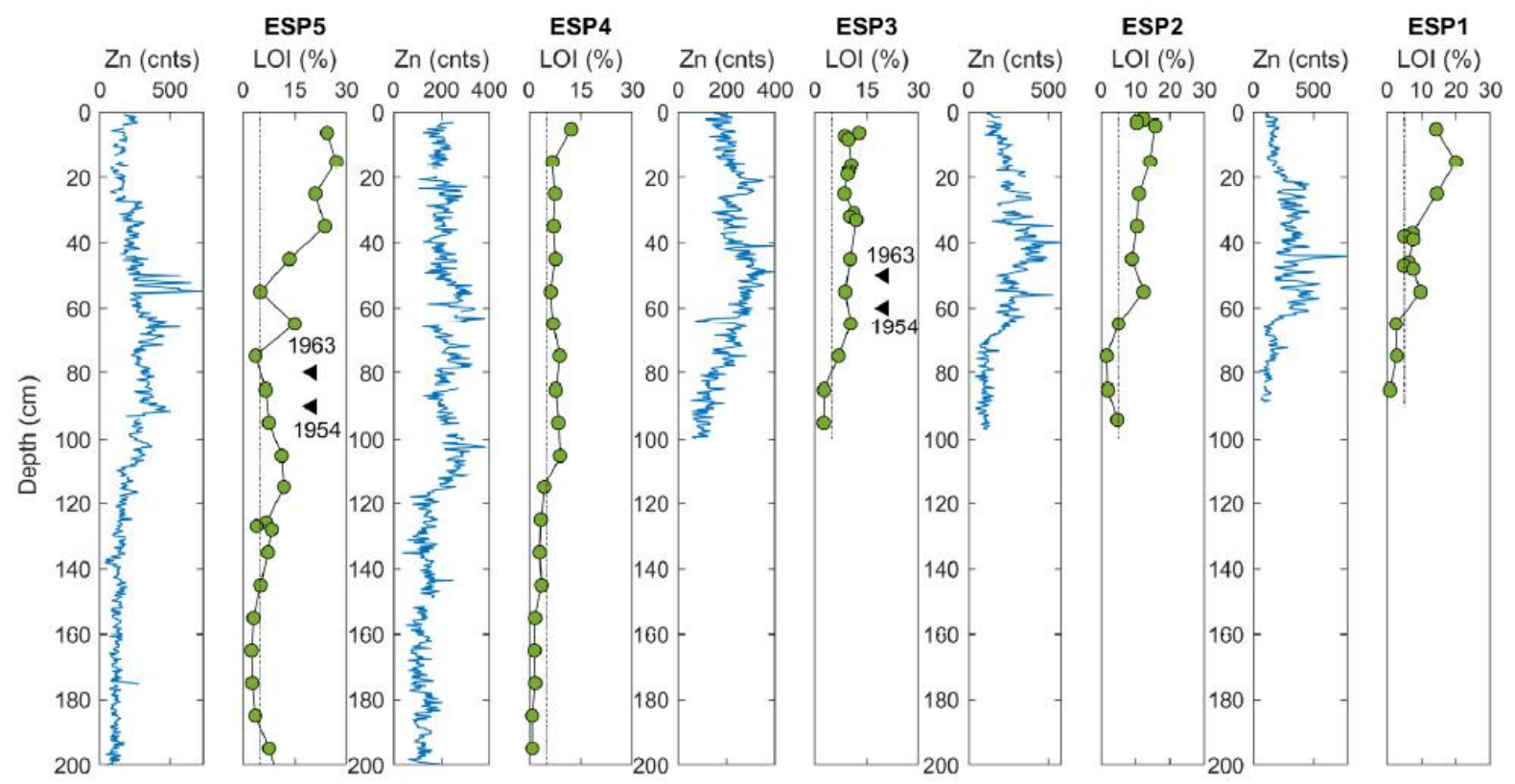

Fig. 10: Depth profiles from tidal wetlands on the Esopus delta of Zn (blue), and LOI (green). Triangles in LOI panel for ESP5 and ESP3 denote depths of ${ }^{137} \mathrm{Cs}$ derived ages $\left({ }^{137} \mathrm{Cs}\right.$ data for ESP3 shown in Fig. 9).

1029

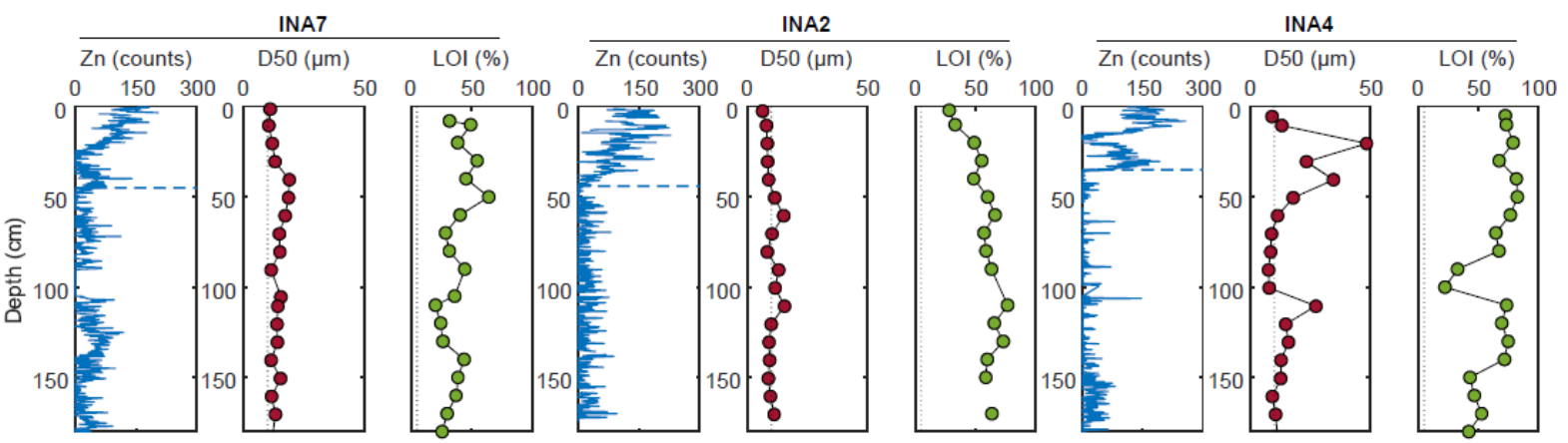

1030

1031

1032

1033

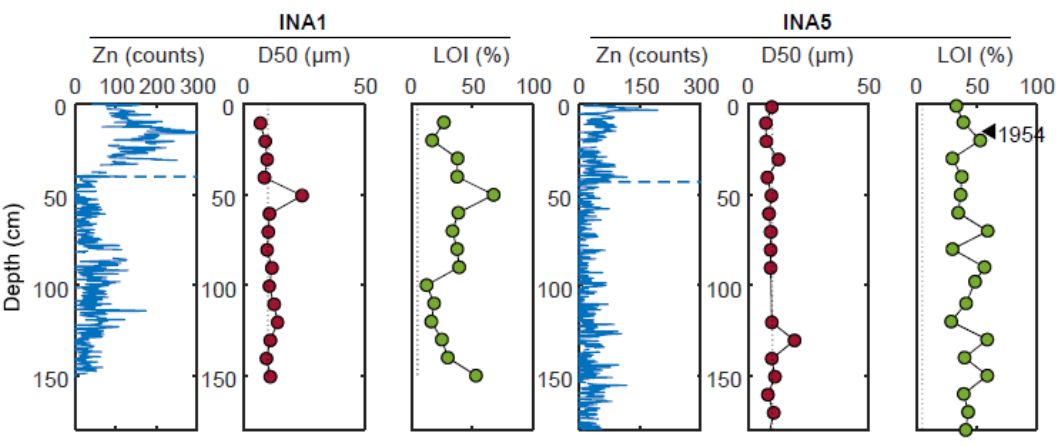

1034

Fig. 11: Depth profiles of Zn (blue), median grain size (D50, red) and LOI (green) for the five core transect from lona Marsh (see Fig. 1 for locations). A blue line denotes interpreted onset for Zn. Triangles denote depths of ${ }^{137} \mathrm{Cs}$ derived age for INA5. 

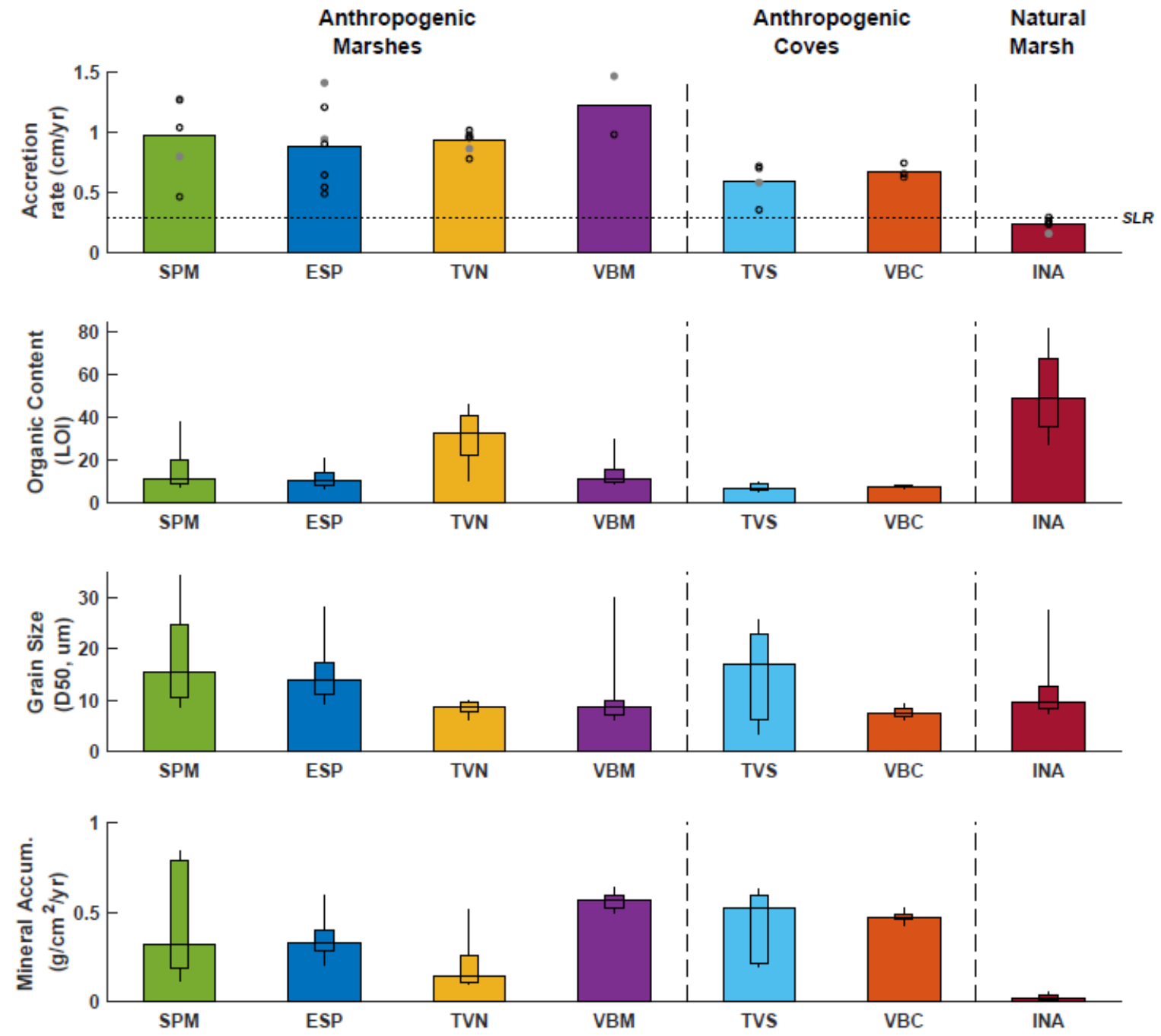

1035

1036

Fig. 12: Distributions of accumulation rates, organic content, median grain size, and inorganic mineral accumulation rates for each study site. Filled gray and open black circles in upper panel are based on $1954{ }^{137} \mathrm{Cs}$ onset and $\mathrm{Zn}$ chronologies, respectfully. Average rates of relative $20^{\text {th }}$ century sea level rise (SLR) as measured at the Battery, NY (NOAA, 2019), provided as a horizontal dotted line. The wider bar in all plots indicate median value for each site. Inner rectangle in lower three panels represents the $25^{\text {th }}$ and $75^{\text {th }}$ percentiles and ends of outer line the $10^{\text {th }}$ and $90^{\text {th }}$ percentiles of all measurements within top $50 \mathrm{~cm}$. 


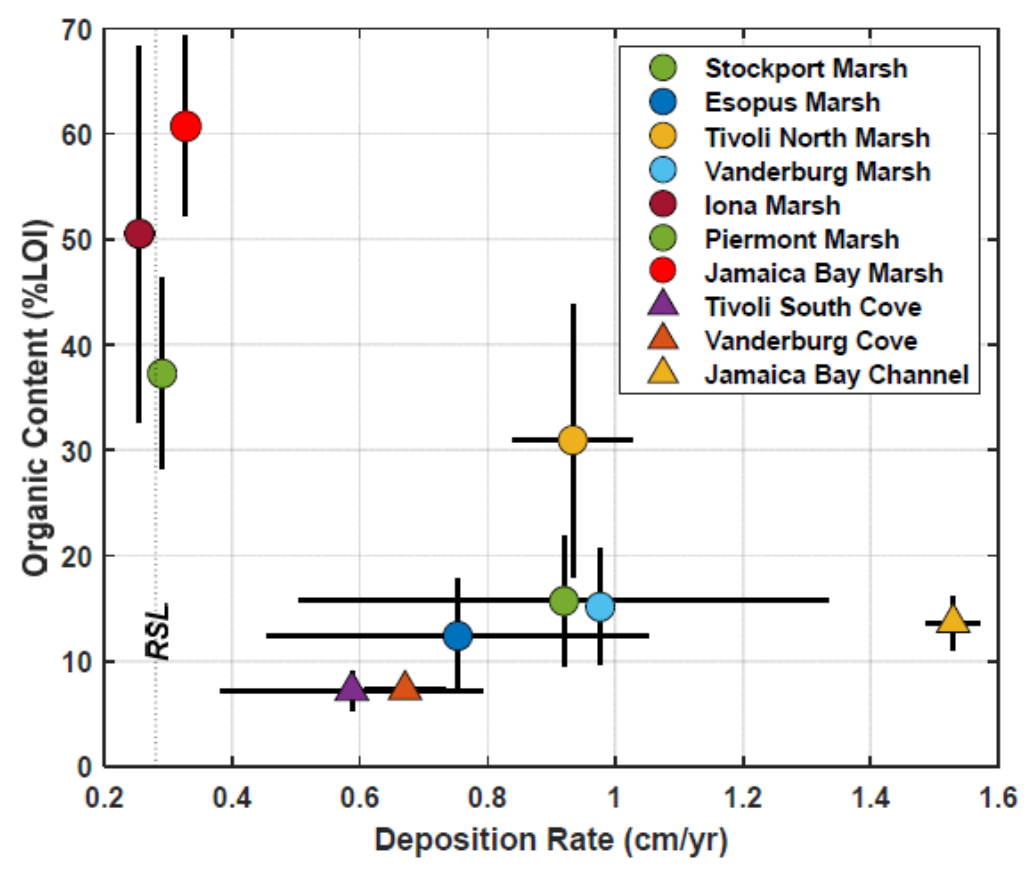

1044

1045 Fig. 13: Average organic content within the top $50 \mathrm{~cm}$ of tidal marshes (circles) and muddy

1046 environments (triangles) as a function observed deposition rates. Sites from this study include Stockport 1047 Marsh (SPM), Esopus Marsh (ESP), Tivoli North Marsh (TVN), Vanderburgh Marsh (VBM), Tivoli South 1048 Bay (TVS), Vanderburgh Cove (VBC), and lona Marsh (INA). Also presented are data from Piermont 1049 Marsh (Pederson et al., 2005), Jamaica Bay dredged channel (Bopp et al., 1993), and Jamaica Bay Marsh 1050 (Peteet et al., 2018). Error bars represent 1 standard deviation. 


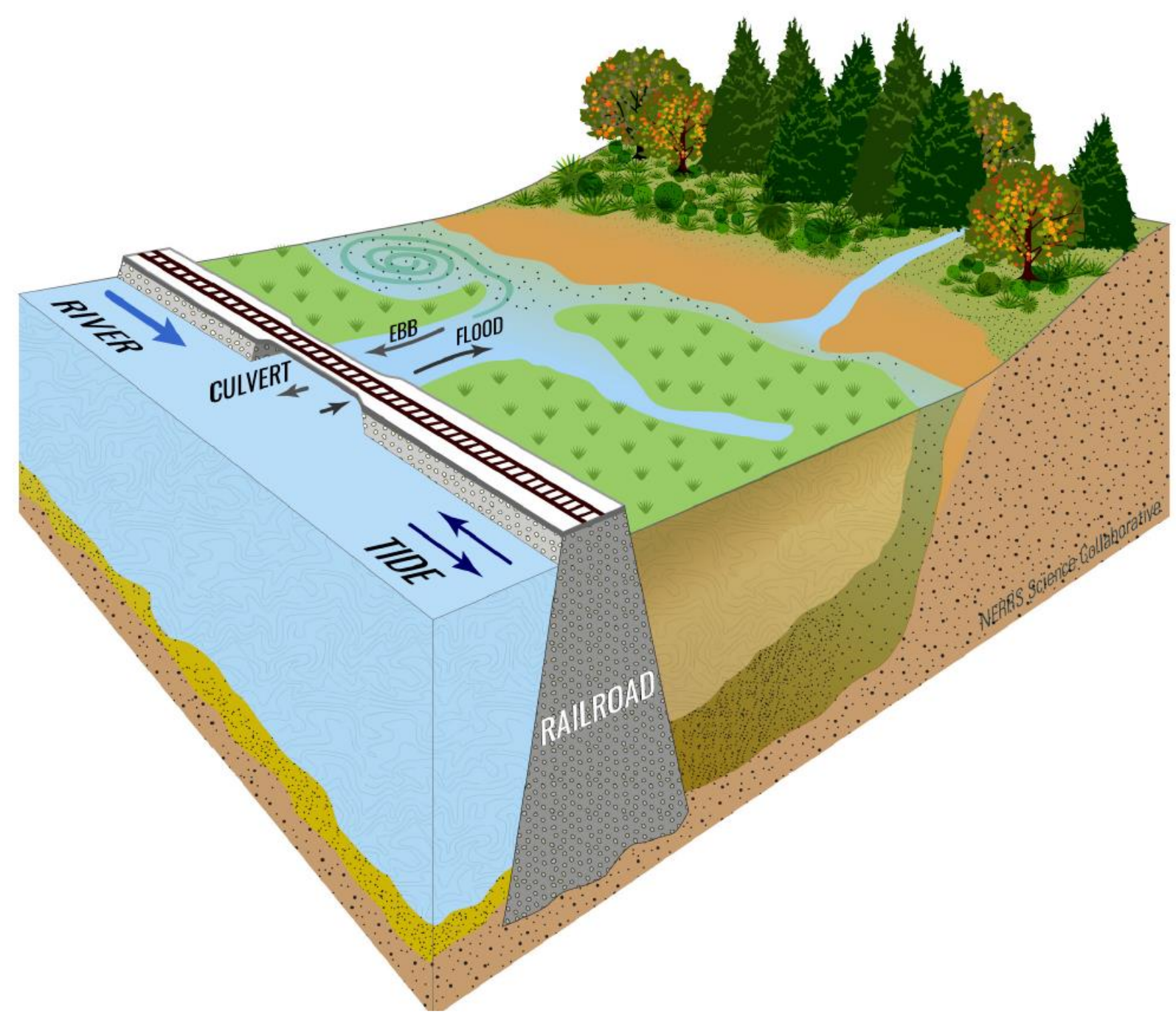

1053 Fig. 14: Schematic diagram of mature marsh developed in the shelter of a railroad berm. Thick blue 1054 arrow depicts net river flow, with tidal fluxes indicated in black. 

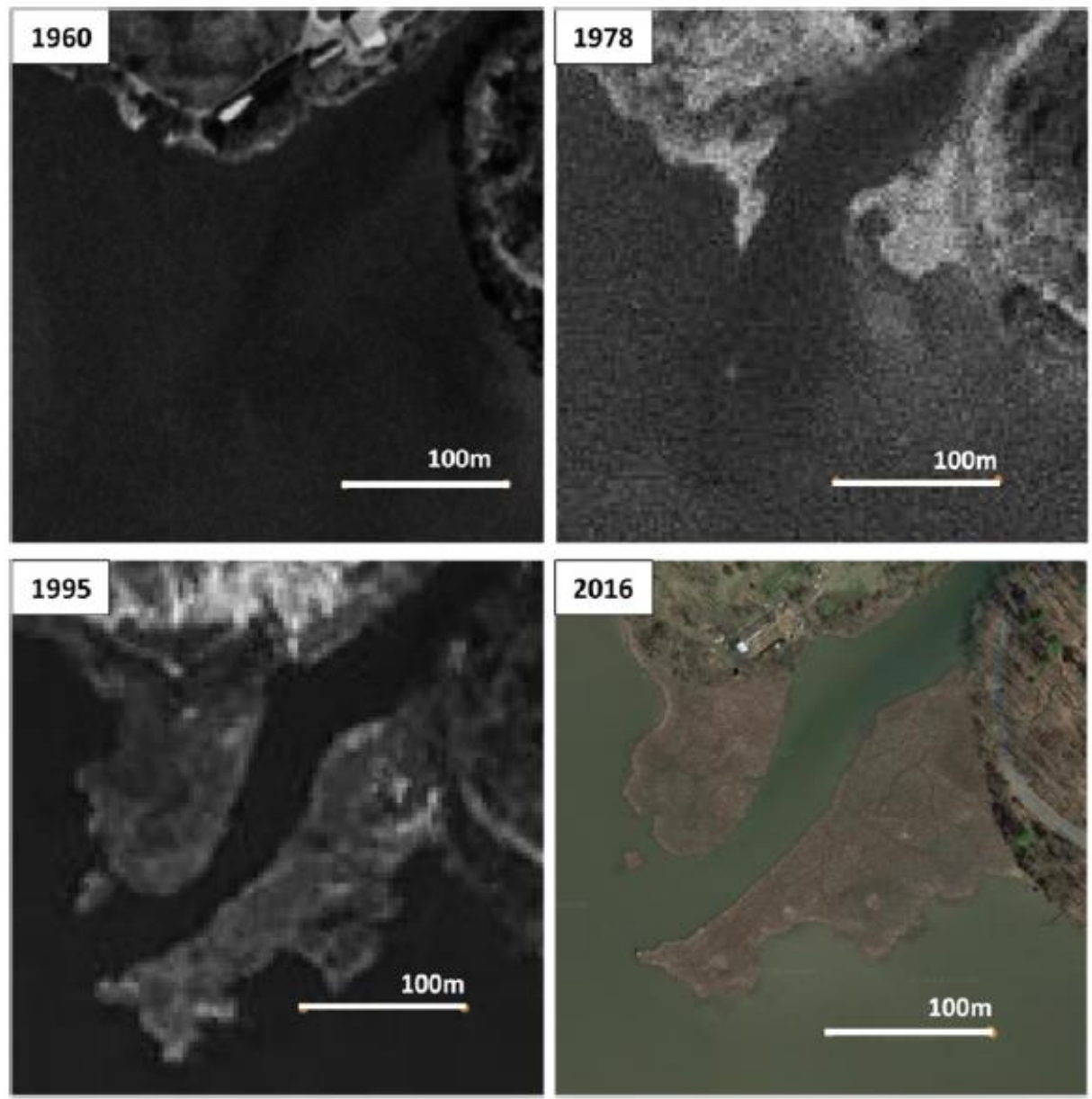

1058

1059 Supp. Fig. 1 - Historic air photos of the mouth of Landsman Kill Creek in Vanderburgh Cove (41.88, -

1060 73.93, see Fig 1D for context). No marsh was present in 1960 (top left). Limited marsh had developed by 10611978 and expanded rapidly between 1978 and 1995. There does not appear to have been much marsh 1062 expansion between 1995 and 2016. Aerial photos downloaded from earthexplorer.usgs.gov. 

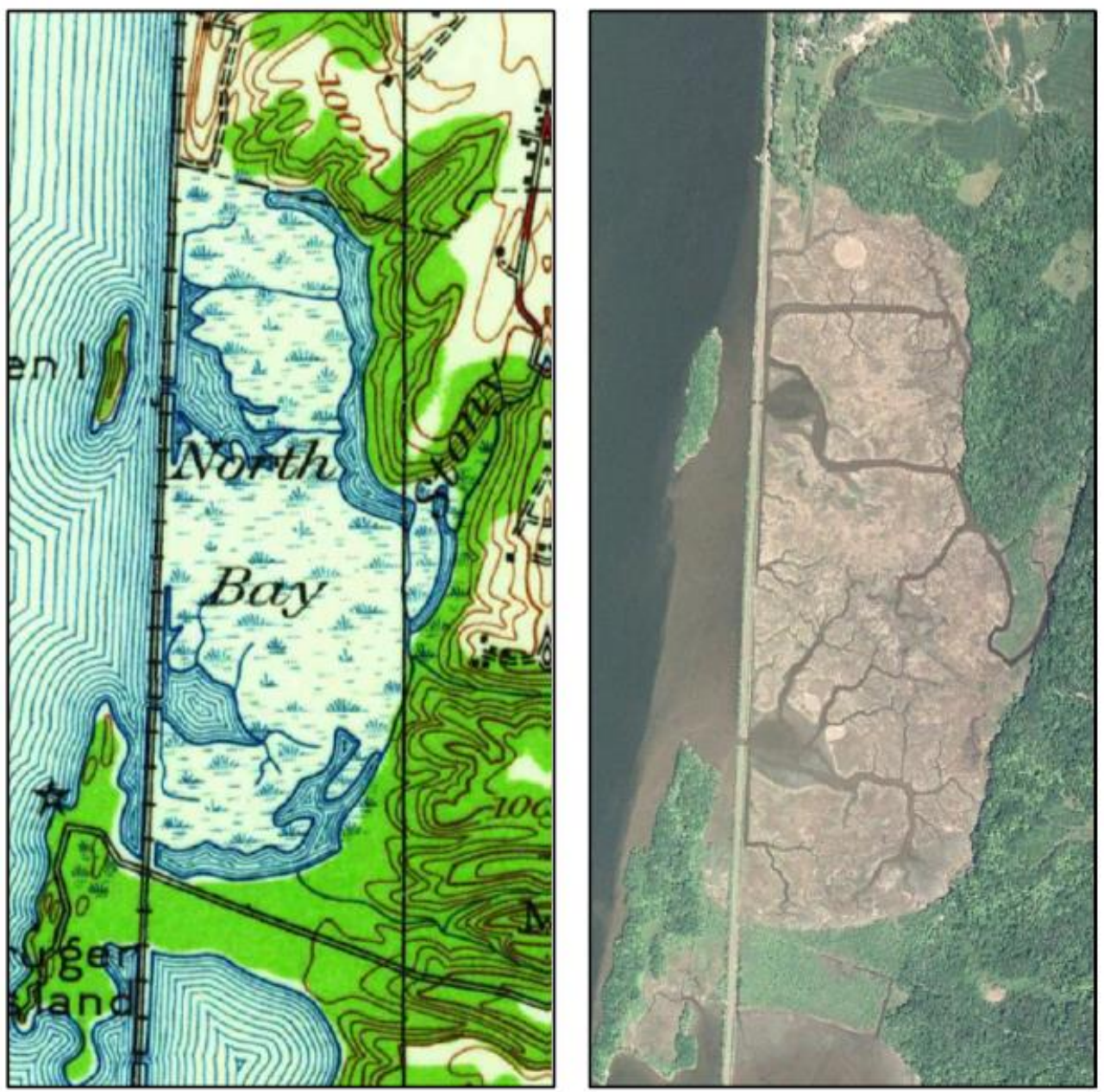

1064

1065

Supp. Fig. 2 - Tivoli North Bay as depicted in a 1934 USGS topographic map (left) and the same location 1066 in October, 2008 (Google Earth). See Fig. 1 for context within broader Hudson River. 

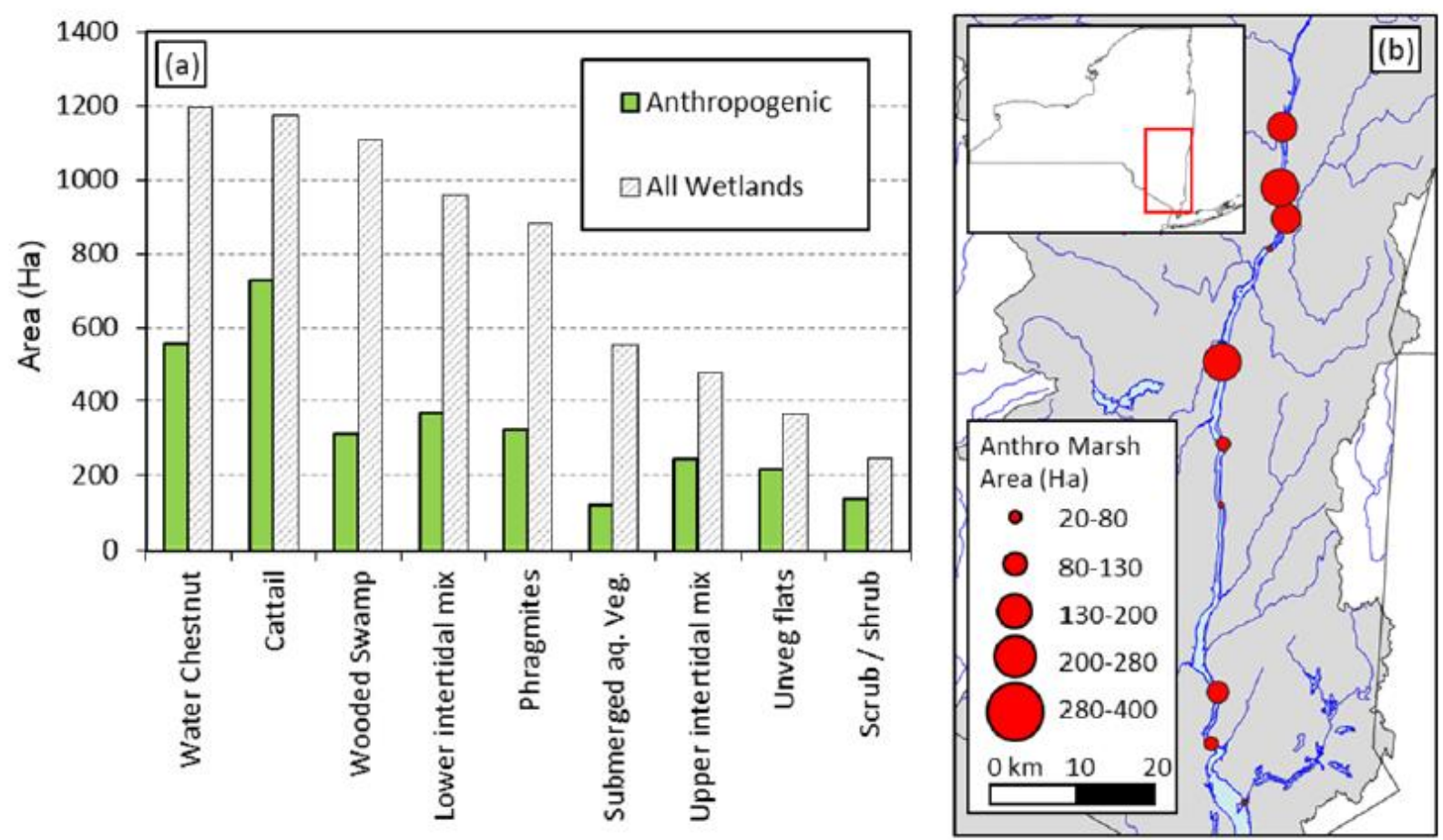

1069 Supp. Fig. 3 - (a) Total area of each type of tidal wetland habitat included in the analysis (Geospatial 1070 Data from Cornell, 2011). (b) Geographic distribution of anthropogenic emergent tidal wetlands along 1071 the Hudson River with the watershed shaded grey. 


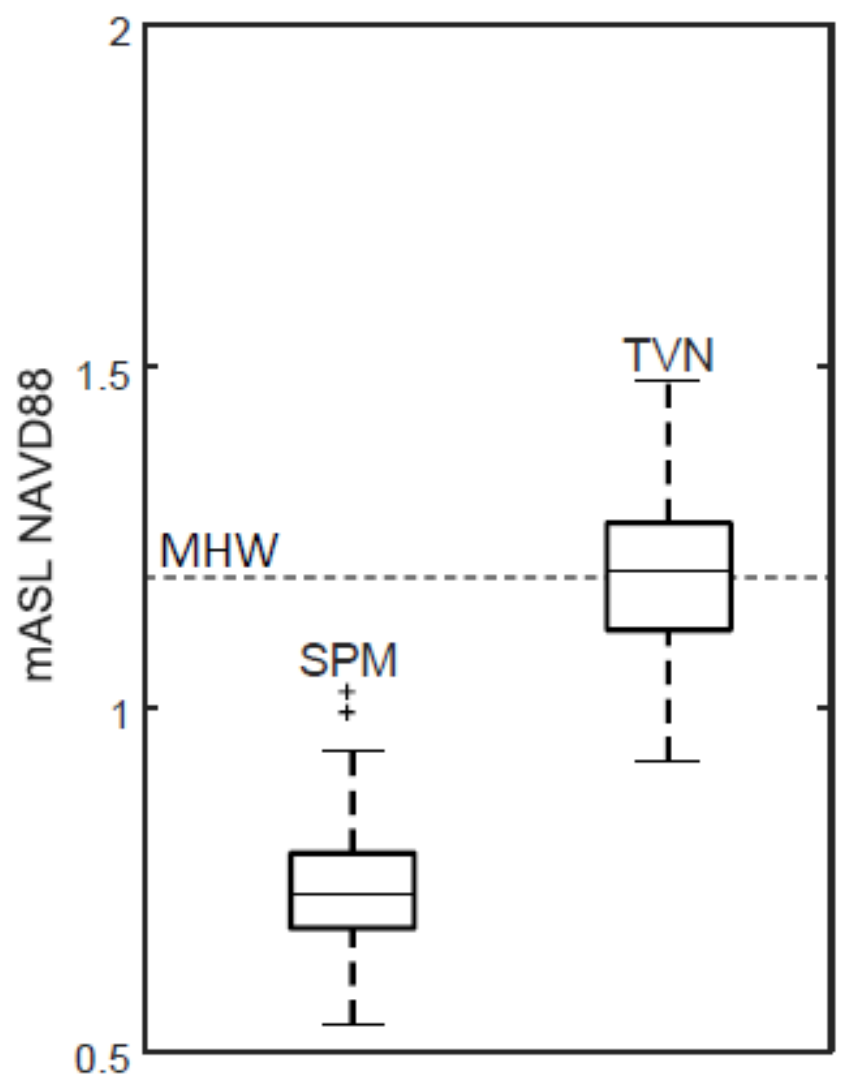

1073 1074

1075

1076

1077
Supp Fig 4 - Box plots of lidar-derived marsh elevations from the marsh platform at Stockport Marsh (SPM) and Tivoli North Marsh (TVN). Data from NYSDEC (2012). Mean high water (MHW) at Turkey Point tide gauge (NOAA 8518962) located across the river from Tivoli, NY. 